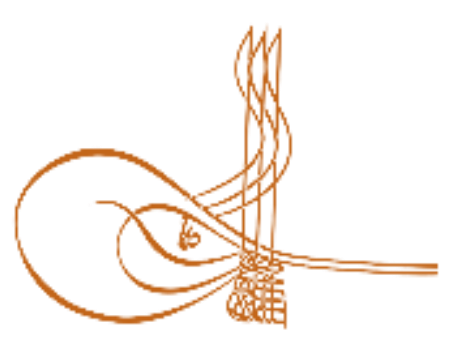

www.turkishstudies.net/turkishstudies
Turkish Studies

eISSN: $1308-2140$

Research Article / Araştırma Makalesi

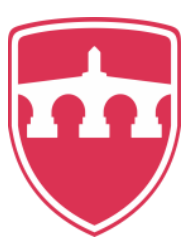

INTERNATIONAL

BALKAN

UNIVERSITY

Sponsored by IBU

\title{
Edirne Hasan Sezai Dergâhı Üzerine Bir İnceleme
}

An Investigation on Hasan Sezai Dervish Convent in Edirne

\author{
Esin Benian* - Arif Misirl1 ${ }^{* *}$
}

\begin{abstract}
The dervish convent which is an indication of the religious order and mystical life is a product of architecture. They are at the forefront of the religious order buildings in their period, where social unity and solidarity are ensured and different actions such as accommodation, conversation and ceremonies are carried out. One of these dervish convents is Hasan Sezai convent located in Edirne, which has been the capital of the Ottoman Empire for almost a century. This convent is in the form of a complex consisting of a mosque, two tombs, a fountain, a shadervan fountain and a burial ground. The aim of this study is to reveal the current architectural features of the mosque, which has been reconstructed in 2015, in addition to the restored tombs and shadervan fountain. Within the scope of this study, based on the literature research and field survey, the life of Hasan Sezai Efendi and the establishment of the dervish convent with its burial ground, shadervan fountain and tombs of the dervishes has been briefly discussed and the architectural features of the mosque were examined in detail. In the conclusion, the dervish convent was ezamined in terms of the buildings it contains; on the other hand, the mosque was discussed based on its function, cover coat style, cover coat technique and ornamentation features, and partly similar buildings of the period were revealed. As a result, many dervish convents were established by the religious orders that became widespread during the Ottoman Period. Hasan Sezai Dervish Convent, one of these dervish convents, has an important place in Edirne's cultural and mystical life. The Dervish Convent represented the branch of the Halveti-Gülşeni religious order, which was established by Hasan Sezai Efendi and called 'Sezaiyye' in proportion to Sezai. Until the beginning of the $20^{\text {th }}$ century, Sezaiyye was the branch representing the Gülşeni religious order in Edirne. Hasan Sezai Dervish Convent shows properties of a complex and the mosque in the Hasan Sezai Dervish Convent functions as a tevithane. Moreoever, the Hasan Sezai Mosque varries from classical mosques which are square or rectengular planned and hipped roofed or domed. These features show the importance of Hasan Sezai Dervish Convent and Hasan Sezai Mosque.
\end{abstract}

Structured Abstract: The dervish convent which is an indication of the sect and mystical life is a product of architecture. They are at the forefront of the sect buildings in their period, where social unity and solidarity

\footnotetext{
* Dr. Öğr. Üyesi, Trakya Üniversitesi, Mimarlık Fakültesi, Mimarlık Bölümü Asst. Prof. Dr., Trakya University, Faculty of Architecture, Department of Architecture ORCID 0000-0001-5053-8325

esinbenian@yahoo.com.tr

** Dr. Öğr. Üyesi, Trakya Üniversitesi, Mimarlık Fakültesi, Mimarlık Bölümü

Asst. Prof. Dr., Trakya University, Faculty of Architecture, Department of Architecture ORCID 0000-0003-2183-0532

arifmisirli@gmail.com
}

Cite as/ Atıf: Benian, E., Mısırl1, A. (2020). Edirne Hasan Sezai Dergâhı üzerine bir inceleme, Turkish Studies, 15(2), 807-830. https://dx.doi.org/10.29228/TurkishStudies.41562

Received/Geliş: 31 January/Ocak 2020

Accepted/Kabul: 25 April/Nisan 2020

Checked by plagiarism software

Copyright (C) MDE, Turkey 
are ensured and different actions such as accommodation, conversation and ceremonies are carried out. One of these dervish convents is Hasan Sezai convent located in Edirne, which has been the capital of the Ottoman Empire for almost a century.

This study aims to reveal the current architectural features of the mosque, which has been reconstructed in 2015, in addition to the restored tombs and shadervan fountain. Within the scope of the study, the life of Hasan Sezai Efendi and the establishment of the dervish convent has been briefly discussed, the burial ground, shadervan fountain, and tombs of the dervish convent were mentioned and the architectural features of the mosque were examined in detail.

The dervish convent represented the branch of the Halveti-Gülşeni sect, which was established by Hasan Sezai Efendi and called 'Sezaiyye' relative to Sezai. Although the entrance of Gülşeniye to Edirne started with Aşık Musa in the 16th century, Hasan Sezai and his successors appealed to the wider audience. Until the beginning of the 20th century, Sezaiyye was the branch representing the Gülşeni sect in Edirne.

Today, the dervish convent surrounded by walls from three directions is located in the southwest of Edirne, in the transition zone of the urban site area. There are Hasan Sezai Efendi Tomb, La'li Fenayi Efendi Tomb, fountain, shadervan fountain and burial ground in the dervish convent area.

Considering the excavation reports and the death date of Shah Melek Bey, it indicates that a zawiya with a wooden roof and a single minaret was built by Shah Melek in the first half of the 15th century (1428). This zawiya named as Shah Melek Zawiya was also used by Aşık Musa Efendi in the 16th century as Gülşeni dervish convent; for this reason, it can be said that its name is also known as Gülşeni dervish convent.

According to the data obtained from the repair information, the building, which was renovated in the early 17 th century, was rebuilt in 1740; it was soon repaired in 1751 . The mosque, which is the main structure of the dervish convent, was also used as tevhidhane (The place where the rite and the salaat are performed in dervish lodges without independent masjids).

The rectangular mosque has two floors. In the center, there is a gallery space. The gallery space is limited by fourteen wooden posts rising in two layers. The first floor is reached by a wooden ladder. On the ground floor, there is a mihrab in the middle of the southeast wall, a minbar on the right of the mihrab and a sermon chair (ambo) on the left. On the first floor, there are rooms behind the gallery in the southeast and southwest direction. There is the last prayer hall extending halfway to the northwestern front of the harim (prayer hall). There is a minaret in the western corner of the mosque.

All the facades of the building are plastered and whitewashed and have two rows of windows. The walls of the building, a built-in masonry system, are brick-lined rough-cut stones. Rare cut stone is also rarely used on the main outer walls. The top of the mosque is inside, with a dome and flat wooden ceiling; on the outside, it is covered with a tiled roof. The dome with wooden construction carried by wooden poles covers the gallery space.

In this study, in which Hasan Sezai Mosque was examined in detail, while the dervish convent was examined in terms of the buildings it contains, the mosque was discussed based on its function, cover coat style, cover coat technique, and ornamentation features and its similarities with the same period buildings are trying to be revealed.

With this perspective in mind, Istanbul Merkez Efendi Dervish Lodge, Istanbul Takkeci Dervish Lodge, Istanbul Corlulu Ali Pasha Dervish Lodge, Istanbul Silivrikapı Bâlâ Dervish Lodge and Istanbul Ertugrul Tekke Mosque can be considered as buildings showing the aspects of the complex with the mosque as the main element such as Hasan Sezai Dervish Convent. Istanbul Sheikh Vefa Dervish Lodge, Konya Pirî Mehmed Pasha Zawiya, Eskisehir Mevlevi Lodge, Ankara Mevlevi Lodge, Istanbul Corlulu Ali Pasha Dervish Lodge and Istanbul Ertugrul Tekke Mosque function like a mosque-tevithane such as Hasan Sezai Dervish Convent. Based on the cover coat style, it can be evaluated that Hasan Sezai Dervish Lodge is similar to Besiktas Yahya Efendi Dervish Lodge, Istanbul Takkeci Mosque-Dervish Lodge, Yenikap1 Mevlevi Lodge, Bursa Karabas-1 Veli Dervish Convent, Besiktas Mevlevi Lodge and Unkapanı Şazelî Dervish Lodge; the cover coat technique used in Hasan Sezai Dervish Convent is similar to the technique used in the constructions of Besiktas Yahya Efendi Dervish Lodge, Bursa Karabas-1 Veli Dervish Convent and Istanbul Ertugrul Tekke Mosque. It can be stated that the ornamentation observed only in the dome of the mosque shows similarity to the ornamentation on the dome of Semahane of the Yenikapı Mevlevi Lodge.

Turkish Studies, 15(2) 
As a result, the Hasan Sezai Dervish Convent shows properties of a complex and the mosque in the Hasan Sezai Dervish Convent functions as a tevithane. Moreoever, the Hasan Sezai Mosque varries from classical mosques which are square or rectengular planned and hipped roofed or domed. These features show the importance of Hasan Sezaii Dervish Convent and Hasan Sezai Mosque.

Keywords: Architecture, Edirne, dervish convent, Hasan Sezai, Hasan Sezai dervish convent, religious order, Sezaiyye.

Öz: Dergâhlar, tarikat ve tasavvufi hayatın göstergesi olan birer mimarlık ürünüdür. Döneminde toplumsal birlik ve beraberliğin sağlandığı; aynı zamanda konaklama, söyleşi, tören gibi farklı eylemlerin gerçekleştirildiği tarikat yapılarının da başında yer almaktadır. Bu dergâhlardan biri de Osmanlı Devleti’ne yaklaşık bir asır boyunca başkentlik yapmış Edirne'de yer alan Hasan Sezai Dergâhı'dır. Bir külliye niteliğindeki dergâh cami, iki adet türbe, çeşme, şadırvan ve hazireden oluşmaktadır. Bu çalışmada amaç, restore edilen türbelerin ve şadırvanın yanı sıra 2015 yılında rekonstrüksiyonu tamamlanan caminin bugünkü mimari özelliklerinin literatüre kazandırılmasıdır. Literatür taraması ve alan çalışması doğrultusunda, çalışma kapsamında Hasan Sezai Efendi’nin hayatı ve dergâhın kuruluşu kısaca irdelenmiş, dergâhtaki hazire, şadırvan ve türbelere değinilmiş, caminin mimari özellikleri ise detaylı olarak incelenmiştir. Sonuç bölümünde dergâh, içerdiği yapılar açısından; cami ise işlev, üst örtü biçimi, üst örtü tekniği ve süsleme özellikleri açısından ele alınarak kısmen döneminin yapıları ile benzerlikleri ortaya konulmuştur.

Sonuç olarak, Osmanlı Dönemi’nde yaygınlık kazanan tarikatlar tarafından birçok dergâh kurulmuştur. Bu dergâhlardan biri olan Hasan Sezai Dergâhı da Edirne'nin kültür ve tasavvufî hayatında önemli bir yere sahip olmuştur. Dergâh, Halveti-Gülşeni tarikatının Hasan Sezai Efendi tarafından tesis edilen ve Sezai'ye nispet ile 'Sezaiyye' adı verilen kolunu temsil etmiştir. Sezaiyye, 20. yüzyıl başına kadar, Edirne'deki Gülşeni tarikatını temsil eden kol olmuştur. Hasan Sezai Dergâhı'nın 15. yüzyıldan itibaren inşasına başlanan tekke ve zaviye gibi benzer nitelikteki yapılar arasında külliye özelliği sergilemesi ve camisinin bir tevhithane işlevine sahip olması açısından da önem taşıdığı görülmektedir. Ayrıca Hasan Sezai Camii'nin kare ya da dikdörtgen planlı, üzeri kırma çatı ya da kubbe ile örtülü klasik camilerden farklılık gösteren mimari özellikleri ile de dikkat çektiği söylenebilir.

Anahtar Kelimeler: Mimarlık, Edirne, Dergâh, Hasan Sezai, Hasan Sezai Dergâhı, Tarikat, Sezaiyye.

\section{Giriş}

Kökeni Orta Asya'ya dayanan tarikatların Osmanlı Devleti'nin kuruluşunda; hatta Osmanlı kimliğinin oluşumunda rolü olduğu söylenebilir. Osmanlı Devleti'ne yaklaşık bir asır boyunca başkentlik yapmış Edirne'de de Müslümanlar arasında bilgi paylaşımını sağlamak ve Türk kültürünü geliştirmek üzere tarikatlar tarafindan birçok dergâh ${ }^{1}$ kurulmuştur. Edirne'nin fethinden itibaren kentin gerek mimarisine gerekse kültür hayatına katkıda bulunan dergâhların Bayramiyye, Bedreddiniyye, Bektaşiyye, Celvetîyye, Halvetîyye, Kadirîye, Mevlevîyye, Nakşîbendîyye, Rifâiyye, Sadiyye, Semerkandiyye ve Zeyniyye olmak üzere on iki ana tarikat ve bunlara bağlı farklı kollar tarafından oluşturuldukları belirtilmektedir (Akçı1, 2013: 25). Edirne'de etkileri olan bu tarikatların başında, Halvetiliğin bir kolu olan ve İbrahim Gülşeni’ye nispet edilen Gülşenîyye (Gölpınarlı, 1969: 207) ile Gülşeniliğe bağlı bir kol olan ve Şeyh Hasan Sezai'ye nispet edilen Sezâiyye (Akç11, 2013: 27, Şimşek, 2008: 84) gelmektedir.

\section{Hasan Sezai'nin Hayatı}

Halveti-Gülşenî tarikatının Sezaiyye kolunun kurucusu ve şairdir (Kazancıgil ve Gökçe, 2005: 60; Konur, 2009: 79; Yazıc1, 1966: 547). As1l adı Hasan olup 'Sezai'nin ona mahlas olarak

\footnotetext{
1 Farsça "kapı" anlamına gelen Dergâh, tarikat yapıları arasında önem bakımından daha aşağı sayılan zikir ve toplantıların gerçekleştiği mekânlar olarak kabul edildiği gibi büyük tekkelere de dergâh denildiği bilinmektedir. Detaylı bilgi için bkz. Ahmet Işı Doğan, Osmanlı Mimarisinde Tarikat Yapıları, Tekkeler, Zaviyeler ve Benzer Nitelikli Fütüvvet Yapıları, (İstanbul: İ.T.Ü. Mimarlık Mühendislik Fakültesi Matbaası, 1977), s. 78.
} 
Niyazi-i Mısri tarafından verildiği belirtilir (Konur, 2009: 79; Yazıc1, 1966: 547). 1669'da (H. 1080) Mora Yarımadası'ndaki Gördes'te (bugünkü Korent) doğmuştur (Kılıç, 2004: 221; Özuygun, 1995: 8; Kazancıgil ve Gökçe, 2005: 60; Konur, 2009: 79; Yazıc1, 1966: 547). Babası Ali, dedesi Kurtbeyzade Hasan'dır (Konur, 2009: 79; Yazıc1, 1966: 547; Özuygun, 1995: 8). Aslında Kurtbeyzade'nin de Kutlubeyzade olduğu belirtilmektedir (Erkurt, 2008: 33).

1687 'de (H. 1098 Ramazan), Venediklilerin Mora'yı işgali üzerine, 18 yaşında iken bir gemi ile İstanbul'a gelmiştir (K1lı̧, 2004: 221; Konur, 2009: 80; Özuygun, 1995: 9; Yazıc1, 1966: 547). Gemide tanıştığı bir Halveti şeyhinin etkisiyle tasavvufa ilgi duymaya başlamıştır. Kısa bir süre İstanbul'da kaldıktan sonra aynı yıl Edirne'ye geçmiştir. Edirne'de piyade mukabelecesi Ali Bey'in yardımıyla mukabele kaleminde çalışmaya başlamıştır (Konur, 2009: 80; Özuygun, 1995: 9; Yazıc1, 1966: 547). Tasavvufa ilgisinden dolayı resmi görevi dışındaki zamanlarında bilgisini arttırmaya çalışmış; İbrahim Gülşenî tarafından tesis edilen Gülşeniyye tarikatının halifelerinden Aşık Musa'nın dergâhında Şeyh Mehmet Sırrî Efendi'ye mürit olmuştur (Konur, 2009: 80; Özuygun, 1995: 10; Yazıc1, 1966: 547). Ancak Sezai’nin Şeyh Mehmet Sırrî Efendi’ye değil, Şeyh Mehmet Sırrî Efendi'nin oğlu ve vekili olan Seyyid Ali Efendi'ye mürit olduğuna dair bilgi de mevcuttur (Özuygun, 1995: 10).

Şeyh Mehmet Sırrî Efendi'nin yaklaşık iki yıl sonra ölümü üzerine, yerine geçen Mehmed La'li Fenai Efendi'ye bağlanmıştır. Şeyhi tarafından dergâhın vakıf gelirlerini toplamakla da görevlendirilmiş; bu görevinden sonra 'Cabi Dede Efendi' unvanını da almıştır (Özuygun, 1995: 10; Yazıc1, 1966: 547). Eğitimini Mehmed La'li Fenai Efendi'den tamamlayan Hasan Sezai, hilafet alarak Gülşeni Veli Dede Dergâhı'nda post-nişin (tekke şeyhi) olmuştur. 1700-01'de (H. 1112) Mehmed La'li Fenai Efendi'nin vefatı üzerine yerine geçen Mahmud Hamdi Efendi altı ay gibi kısa bir süre sonra vefat edince Hasan Sezai yürütmekte olduğu görevini damadi ve kendi halifesi olan Ahmed Müsellim Efendi'ye bırakarak Fenai Efendi'nin faaliyet gösterdiği Aşık Musa Dergâhı'na şeyh olmuştur (K1lıç, 2004: 221; Konur, 2009: 80; Özuygun, 1995: 12; Yazıc1, 1966: 547). Aşsk Musa Dergâhı'nda (kendi adıyla da anılan Hasan Sezai Dergâhı'nda) yaklaşık otuz sekiz yıl boyunca şeyhlik yapmış; bu dönemde Mısır'a giderek Gülşeni Dergâhı'nın şeyhi olan İbrahim Çelebi'den icazet alarak Gülşeniliğin ikinci piri olarak kabul edilmiş (Konur, 2009: 80; Özuygun, 1995: 13) ve 29 Aralık 1738'de (H. 17 Ramazan 1151) Edirne'de vefat etmiştir (Konur, 2009: 80; Özuygun, 1995: 15; Yazıc1, 1966: 547).

Yaşadığı süreçte tekke ve divan edebiyatı üzerine çalışmaları ile şöhret kazanan Sezai'nin üslup ve ifade bakımından başarılı bir şair olduğu da belirtilmektedir (Konur, 2009: 80; Özuygun, 1995: 18; Yazıc1, 1966: 548). Beş kaside, iki terkibibend, 12 murabba, iki muhammes, iki tahmis, iki müseddes, 396 gazel, altı rubai, 33 nazım, $10 \mathrm{kıta,} \mathrm{üç} \mathrm{tarih,} \mathrm{altı} \mathrm{müfred,} 31$ matta' ve yedi ilahiden meydana gelen Divan adlı eseri, hayatta olduğu dönemde (H. 1145-1150 tarihlerinde) La'li Mehmed Fenai'nin divançesiyle birlikte basılmıştır (Konur, 2009: 80). Döneminin tarikat hayatı, tarihi olayları ve şahsiyetleri ile ilgili bilgiler içermekle birlikte oğluna, damadına, halifelerine, müridlerine, yakın çevresine ve bazı devlet ricaline yazdığı mektuplardan oluşan Mektubat-1 hazret-i Sezai adlı eseri La'li Mehmed Fenai'nin Şerh-i Manevi-i Şerif adlı eseri ile birlikte yayımlanmıştır (Konur, 2009: 80; Özuygun, 1995: 20). Şerh-i Gazel-i Niyazi-i Mısri adlı eseri ise "Niyazi-i Mısri'nin, "Halk içre bir ayineyim herkes bakar bir an görür" mısrasıyla başlayan gazelinin açık ve sade bir dil ile izah edilmesi olup Abdullah Çaylığlu'nun hazırladığı Niyazi-i Mısri Şerhleri adlı eserde ve Şahver Çelikoğlu'nun hazırladığı divanının sonunda yer almıştır (Konur, 2009: 80).

\section{Sezaiyye Tarikatı}

Hasan Sezai tasavvuf yolunda Şeyh İbrahim Gülşeni’nin kurduğu Gülşeni tarikatına bağlanmıştır. Gülşenilik, Dede Ömer Ruşeni’nin kurduğu Ruşenilik’ten, Ruşenilik de Şeyh Ebu Abdullah Siraceddin tarafindan kurulan Halvetilik’ten doğmuştur (Canım, 2003: 7). Gülşeniler Edirne'ye daha 16. yüzyılda Aşık Musa (Ö. 1567) ile girmiş; fakat belli bir kitleye hitap 
edememişlerdir. Edirne'yi tarikatın adeta merkezi konumuna taşıyanlar Hasan Sezai ile halefleri olmuştur (Kılıç, 2004: 220). Hatta Hasan Sezai, mensubu bulunduğu Gülşeniliğe nisbetle Sezayi-i Gülşeni olarak bilinmekle birlikle kendisi de Gülşeniliğin Sezaiyye kolunu kurmuştur (Canım, 2003: 7). Dolayısıyla Hasan Sezai tarafından Halveti-Gülşeni tarikatının bir kolu olarak kurulan (Kılıç, 2004: 221; Özuygun, 1995: 24) ve Sezai'ye nispet ile 'Sezaiyye' adı verilen bu tarikat (Özuygun, 1995: 24; Yazıcı, 1966: 549) daha çok Edirne ve çevresinde yaygınlık kazanmıştır (Konur, 2009: 80). Nitekim Sezai'nin ifadesine dayanarak, Edirne ve çevresinde beşyüz bine yakın evli dervişin varlığından söz edilmektedir (Kılıç, 2004: 221; Özuygun, 1995: 24; Yazıc1, 1966: 549).

Halvetiye'den ayrılan kolların sadece belirli zaman ve yerlerde ün salmış şeyhlerin adlarına izafe edilmekten başka büyük bir fark göstermedikleri belirtilmekle birlikte Sezaiyye'nin, bağlı bulunduğu Gülşeniyye gibi, Halvetiye'nin esasını teşkil eden halvet ve zikri muhafaza etmekle beraber az da olsa diğer tarikatların tesiri altında kaldığı, Nakşibendi tarikatının esaslarını bildiği ve Mevlevilere karşı saygı ve yakınlık duyduğu öne sürülmektedir (Özuygun, 1995: 24; Yazıcı, 1966: 549). Ayrıca Sezai'nin şeyhi La'li'nin Şabaniyye, Uşşakıyye, Gülşeniyye, Sünbüliyye, Nakşibendiyye tarikatlarından icazeti olduğunu, Sezaiyye'nin Gülşeniyye'nin bir şubesi olarak görünmekle birlikte bu beş tarikatı da içerdiği ifade edilmektedir. Hatta Sezai, Uşşakıyye'den ayrılan şubelerin beşincisinin kurucusu olarak zikredilmektedir (Konur, 2009: 80).

Sezaiyye, Edirne'deki Gülşeni tarikatını 20. yüzyıl başına kadar temsil eden kolu olmuştur. Bununla birlikte Sezai'nin Edirne dışında Gördes'te doğup büyüdüğü evini bir zaviye ${ }^{2}$ haline getirdiği; Eğriboz, Yeniş̧ehir ve Edirne'deki dergâha bağlı başka zaviyeler de kurduğu; halifeleri ile nüfusunu Edirne dışına yaydığı öne sürülmektedir (Kılıç, 2004: 221; Özuygun, 1995: 25; Yazıcı, 1966: 549).

Sezai'nin ölümünden sonra tarikatın şeyhi, oğlu Mehmed Sadık olmuştur. Ancak kısa süre sonra (H. 1151, M. 1761-62'de) ana vatanı Gördes'e gittiğinden yerine oğlu Çelebi Hasan Efendi geçmiştir (Özuygun, 1995: 25; Yazıc1, 1966: 549). Mehmed Sadık Efendi’nin aynı yıl Gördes’teki hankahta $^{3}$ vefat etmesi üzerine dergâhta toplanan tarikat üyeleri tarafından Sezai'nin damadı ve halifesi olan Hafız Mustafa Efendi halife seçilmiştir. Hafız Mustafa Efendi 5 yıl sonra (H. 1180, M. 1766) Cihangir'de Tatar Hasan Dede hankahında vefat etmiş (Özuygun, 1995: 16) ve ardından sırasıyla Çelebi Hasan Efendi'nin torunları olan Mahmud Efendi ile Ahmed Efendi, Mahmud Efendi'nin oğlu Şeyh Mehmed Efendi ve Çelebi Hasan Efendi'nin torunu Şeyh Mehmed Efendi post-nişin olmuşlardır. Şeyh Mehmed Efendi'nin H. 1289'da (M. 1872-73) bu mevkide bulunduğundan söz edilmektedir (Yazıc1, 1966: 549). Bu durumda Sezai Efendi'nin ölümünden sonra irşat görevini yerine getirenlerin çocukları ve torunları olduğu; onların da 19. yüzyıl sonuna kadar bu görevi sürdürdükleri anlaşılmaktadır.

\section{Hasan Sezai Dergâhı}

3.1. Konumu: Dergâh, kentin güneybatısında, kentsel sit alanı etkileme geçiş bölgesinde, Talatpaşa Mahallesi sınırları içerisinde yer almaktadır (Şekil 1). Yapılar topluluğundan oluşan dergâh kuzeybatıda, Kavaklı Tekke Sokak; güneydoğuda, Hanımoğlu Sokak; güneybatıda da Bostanpazarı Caddesi ile sınırlıdır (Şekil 2). Dergâh alanına giriş, biri Kavaklı Tekke Sokak

\footnotetext{
2 "Zaviye", herhangi bir tarikata ait olup içinde dervişlerin yaşadığı ve gelip geçen yolcuların bedava misafir edildiğ yapılar anlamına gelmektedir. XV. ve XVI. yüzyıllardan başlayarak daha çok köylerdeki ve şehirlerdeki küçük tekkeleri belirtmek için kullanılmıştır. Bkz. Ahmet Yaşar Ocak, "Zaviyeler (Dini, Sosyal ve Kültürel tarih açısından bir deneme)", Vakıflar Dergisi, XII (1978), s. 250.

3 "Hankah" dervişlerin sohbet ve zikir için toplandıkları, belirli bir süre ikamet ettikleri; hatta bazen inzivaya çekildikleri mekânlar için kullanılan bir terimdir. Hankah kelimesi Farsça hân "kervansaray, ev, mâbed, sultan"; hân "sofra, eyvan" ve hâne "ev, oda" kelimelerine yer bildiren -gâh ve -geh eklenerek türetilmiştir. Farsça edebi ve tarihi metinlerde hângâh, hânegâh, hâncâh, hângeh gibi çeşitli şekillerde geçen kelime hânkâh olarak Arapçalaştırılmış ve bu şekliyle kullanımı yaygınlık kazanmıştır. Bkz. Süleyman Uludağ: "Hankah”, TDV İslam Ansiklopedisi, 16 (1997), s. 42.
} 
üzerinde; diğeri (ana giriş) de Bostanpazarı Caddesi üzerindeki iki türbe arasında yer alan kapı olmak üzere iki kapıdan sağlanmaktadır.

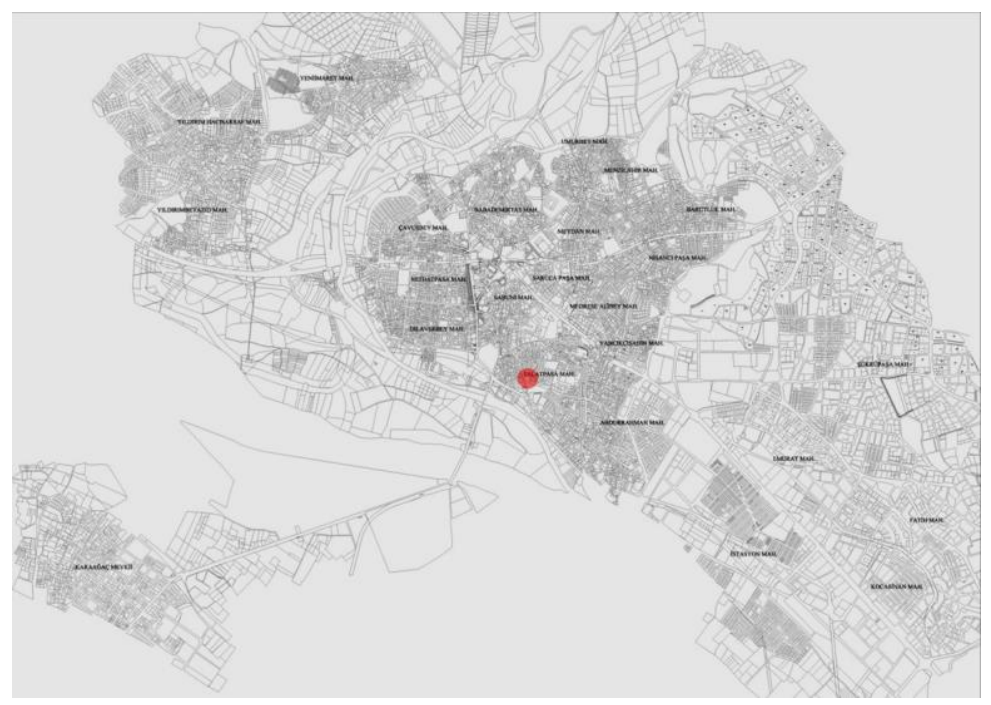

Şekil 1. Hasan Sezai Dergâhı'nın kent içi konumu

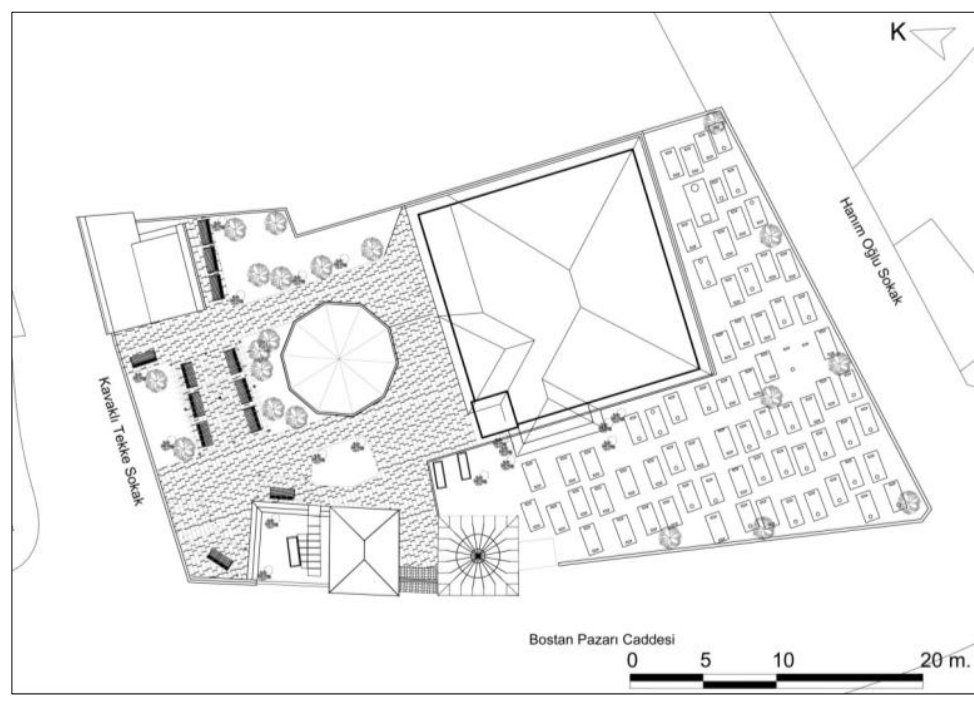

Şekil 2. Vaziyet planı (Edirne V.B.M. arşivi)

Dergâh ana giriș kapısının sağında (güney yönünde) Hasan Sezai Efendi'nin türbesi ile türbenin güneydoğu duvarına bitişik çeşme (Küçükpazar Çeşmesi); solunda ise La'li Fenayi Efendi'nin türbesi yer almaktadır (Şekil 3). Hasan Sezai Türbesi'nin önünde cami; caminin önünde şadırvan; caminin güneyinde ve batısında (Hasan Sezai Efendi'nin türbesinin önü de dahil olmak üzere) da hazire konumlanmaktadır (Şekil 2). çevrilidir.

Dergâh alanı -türbeler ve iki türbe arasındaki dergâh giriş kapısı hariç- bahçe duvarları ile 


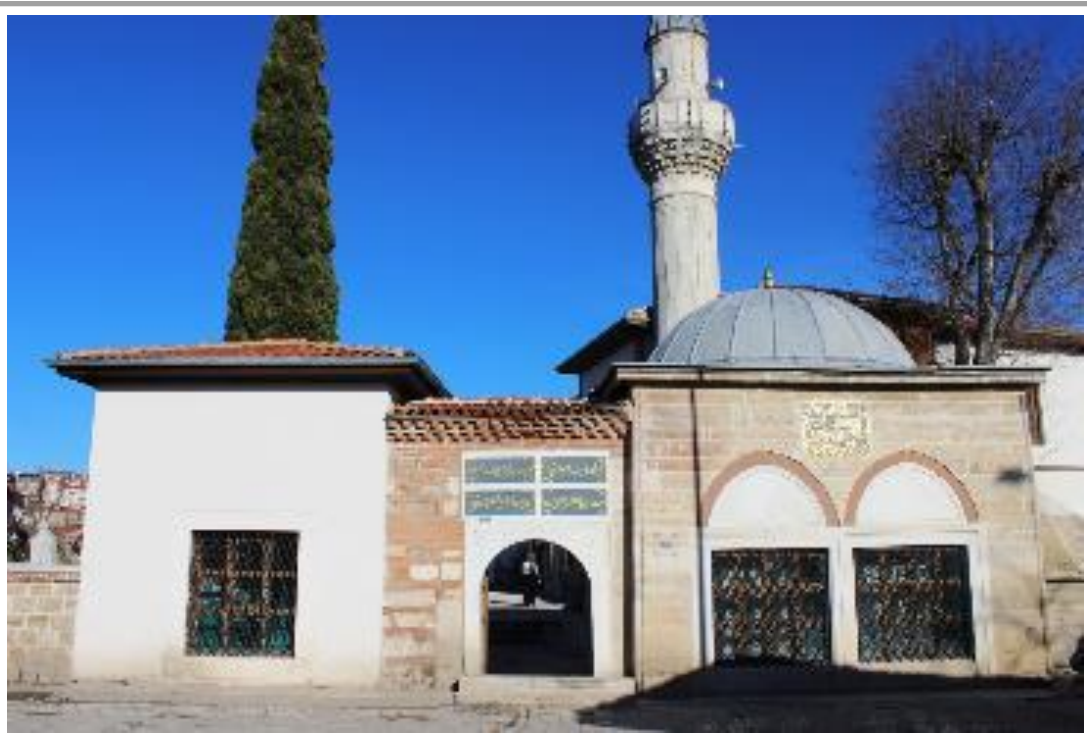

Şekil 3. Dergâh giriş kapısı ve türbelerin batıdan görünümü (solda La'li Fenai Efendi Türbesi, sağda Hasan Sezai Efendi Türbesi/2019)

\subsection{Dergâhtaki Yapılar}

\subsubsection{Hasan Sezai Efendi Türbesi}

Eskiden bir sebzeci dükkanı olduğu belirtilen yap1, Hasan Sezai Efendi'nin vasiyeti üzerine 1738/39 (H. 1151) y1lında türbeye dönüştürülmüştür (Özkan, 1995: 68; Akç11, 2013: 59). 4.28x4.48 metre boyutlarında, kare planlı yapının üzeri pandantif geçişli kubbe ile örtülüdür (Şekil 4, 5). Bu kubbenin 1751 yılındaki onarım sırasında (Ahmet Badi, 2000: 91; Akçı1, 2013: 60) Belgradlı Kamil Ahmet Paşa tarafından yaptırıldığı ifade edilmektedir (Ahmet Badi, 2000: 91).
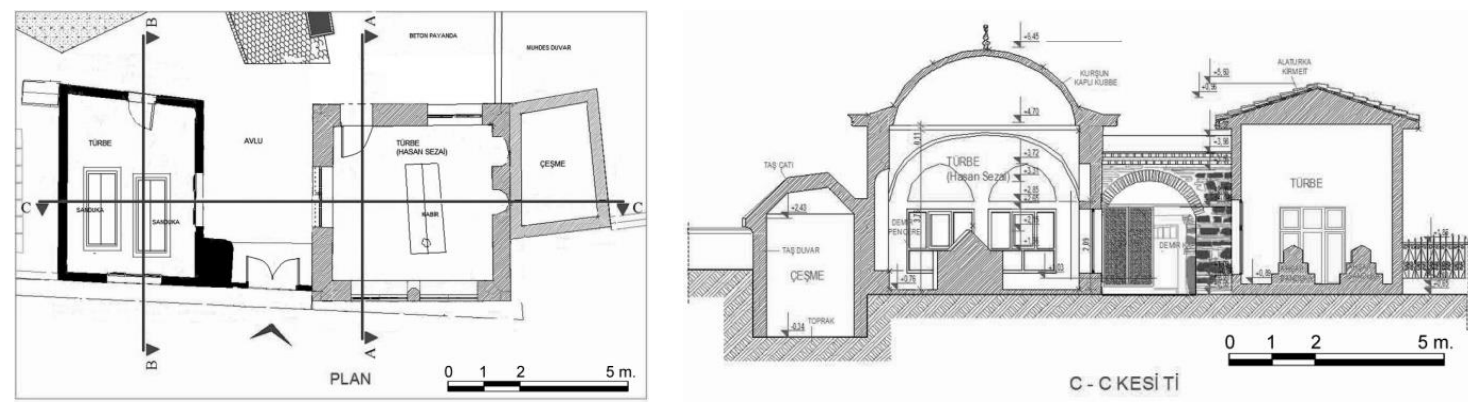

Şekil 4. Türbelerin (solda La'li Fenai Efendi Türbesi, sağda Hasan Sezai Efendi Türbesi) ve çeşmenin planı (Edirne V.B.M. arşivinden yararlanılarak düzenlenmiştir)

Şekil 5. Türbelerin (solda La'li Fenai Efendi Türbesi, sağda Hasan Sezai Efendi Türbesi) ve çeşmenin kesidi (Edirne V.B.M. arşivinden yararlanılarak düzenlenmiştir)

Türbeye giriş, doğu duvarındaki kapıdan sağlanmaktadır. Restorasyon öncesinde türbeye, doğu duvarı önünde, dar-uzun koridor şeklindeki bir giriş holünden geçilerek girilmesine karşın bu holün restorasyon esnasında kaldırıldığı görülmektedir (Şekil 6). İç mekânda Sezai Efendi'nin sandukası yer almakta olup güney duvarı üzerinde ortada bir mihrap nişi, mihrap nişinin iki yanında da yarım daire kemerle sonlanan birer dolap nişi konumlanmaktadır (Şekil 7). Diğer beden duvarlarından doğuda -giriş kapısının güneyinde- bir, batıda iki, kuzeyde de bir pencere konumlanmakta olup dikdörtgen formdaki pencereler kemerli açıklıklar içerisinde yer almaktadır. İç mekân sıvalı ve beyaz badanalıdır. 

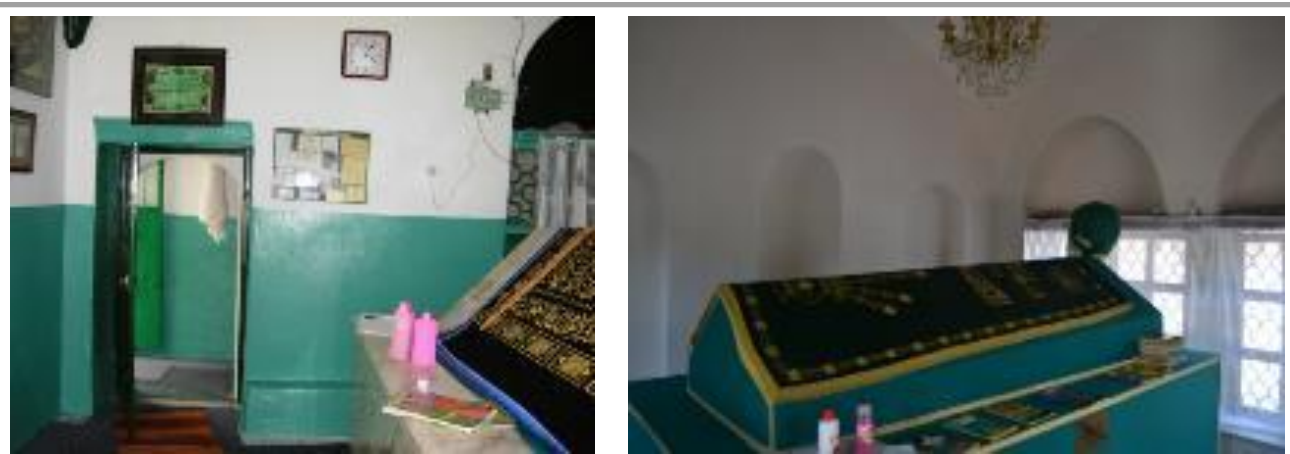

Şekil 6. Türbeden giriş holünün görünümü (Edirne V.B.M. arşivi-2008)

Şekil 7. İç mekânından görünüm (2014)

Düzgün kesme taştan inşa edilmiş türbenin doğu cephesinde, türbeye girişi sağlayan mermer söveli küçük kapıdaki açıklık basık kemer ile geçilmiş; kemerin ortasına çarkıfelek motifi, iki yanına da gül dalından süslemeler yerleştirilmiştir. Kapının üzerinde Hasan Sezai'nin tuğrası (Onur, 1972: 169) konumlanmaktadır. Son onarımda kabartmalar üzerindeki renkler değiştirilerek sadeleştirilmiştir. Daha sonra kapının üzerine tente şeklindeki giriş saçağının eklenmesi tuğranın görünümünün zedenlenmesine yol açmıştır. Giriş kapısının solunda da dikdörtgen formda demir şebekeli bir pencere bulunmaktadır. Cephe sıvalı ve beyaz badanalıdır (Şekil 8, 9, 10).
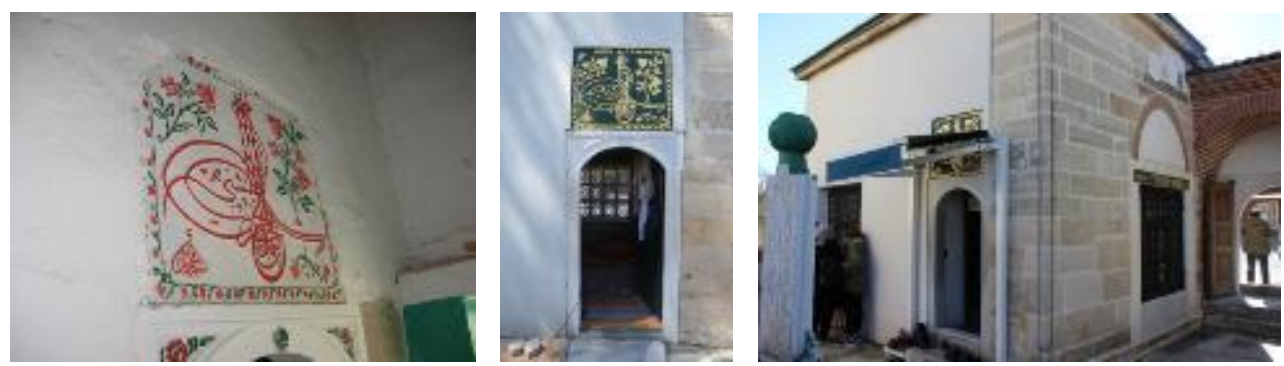

Şekil 8. Restorasyon öncesi türbe giriş kapısı üzerindeki tuğrasından görünüm

(Edirne V.B.M. arşivi-2008)

Şekil 9. Restorasyon sonrası türbesi giriş kapısı (2014)

Şekil 10. Türbenin kuzeydoğudan görünümü (2019)

Türbenin güney cephesi sağır duvardan ibaret olup çeşme bu cepheye bitişik konumdadır. $\mathrm{Bu}$ cephenin çeşmeye bitişik bölümünün üzeri sıvalı ve beyaz badanalıdır (Şekil 11). Düzgün kesme taş yüzeye sahip batı cephesinde ise iki pencere mevcuttur. Kareye yakın dikdörtgen formdaki taş söveli ve lentolu pencereler dıştan demir şebekelidir. Pencerelerin üstünde tuğladan örülü sivri kemerli sağır alınlıklar; iki pencere alınlığının arasında da dört satırlık bir kitabe bulunmaktadır (Şekil 12).
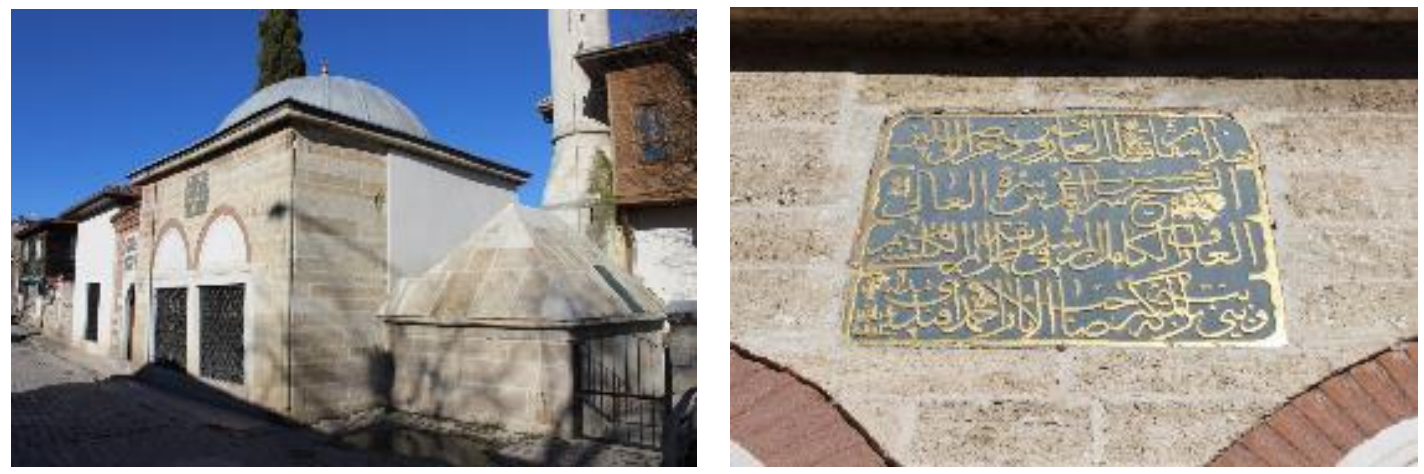

Şekil 11. Türbenin güneyden görünümü ve güney cephesine bitişik çeşme (2019)

Şekil 12. Türbenin batı cephesindeki iki pencere arasında yer alan onarım kitabesi (2019)

Turkish Studies, 15(2) 
Düzgün kesme taş yüzeyli kuzey cephesinde de batı cephesindeki pencerelerle aynı özellikleri sergileyen bir pencere mevcuttur. Bu pencerede dikkat çeken tek farklılık lentonun üzerinde bir yazı kuşağının yer almasıdır (Şekil 10). Tüm cepheler üstte ve köşelerde 2/3'lük dairesel kesitli profil ile sonlanmaktadır.

\subsubsection{La'li Fenai Efendi Türbesi}

Avlunun batı kanadı üzerinde, dergâh giriş kapısının solunda konumlanan türbe 3.50 x 4.66 metre boyutlarında dikdörtgen planlıdır. Düz ahşap tavanlı yapının üzeri kiremit kaplı kırma çatı ile örtülüdür (Şekil 4, 5). Türbeye giriş doğu cephesindeki kapıdan sağlanmaktadır (Şekil 13). Türbede biri La'li Fenai Efendi'nin, diğeri de kaynaklarda Aşık Efendi'ye ait olduğu (Akçıl, 2013: 62) belirtilmekle birlikte üzerinde La'li Fenai Efendi'nin zevcesine ait olduğunu gösteren bilgi levhası görülen iki sanduka yer almaktadır (Şekil 14). Kuzey cephesi sağır olup doğu cephesinde sadece dikdörtgen formda küçük bir giriş kapısı yer almaktadır. Batı ve güney cephesinde de kareye yakın dikdörtgen formda, taş söveli, dıştan demir parmaklıklı birer pencere bulunmaktadır. Yapı içten ve dıştan sıvalı, beyaz badanalıdır.
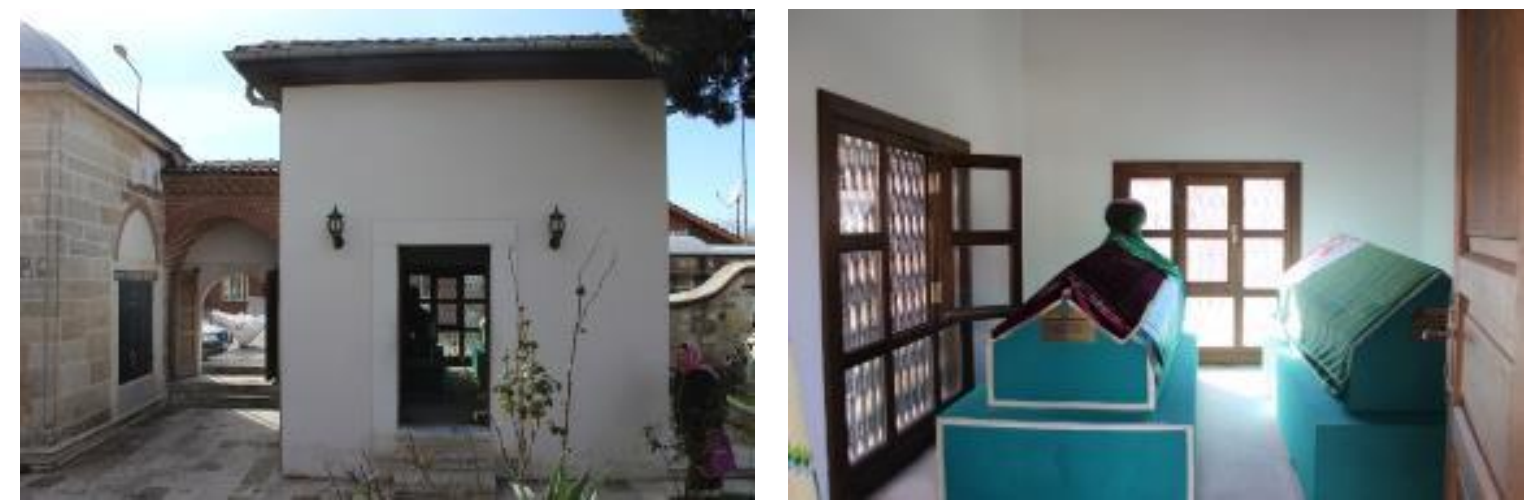

Şekil 13. Türbenin doğudan görünümü (2019)

Şekil 14. Türbenin iç mekânından görünüm (2019)

\subsection{3. Çeşme}

Hasan Sezai Türbesi'nin güney cephesine bitişik olarak kesme taştan yapılmış bir çeşme konumlanmaktadır. Kareye yakın dikdörtgen planlı çeşmenin üzeri taştan kırma çatı ile örtülüdür. Çeşmenin yarıya yakın bölümü ile yalak kısmı yol kotunun yükselmesine bağlı olarak toprak altında kalmıştır (Şekil 4, 5, 11, 15, 16).

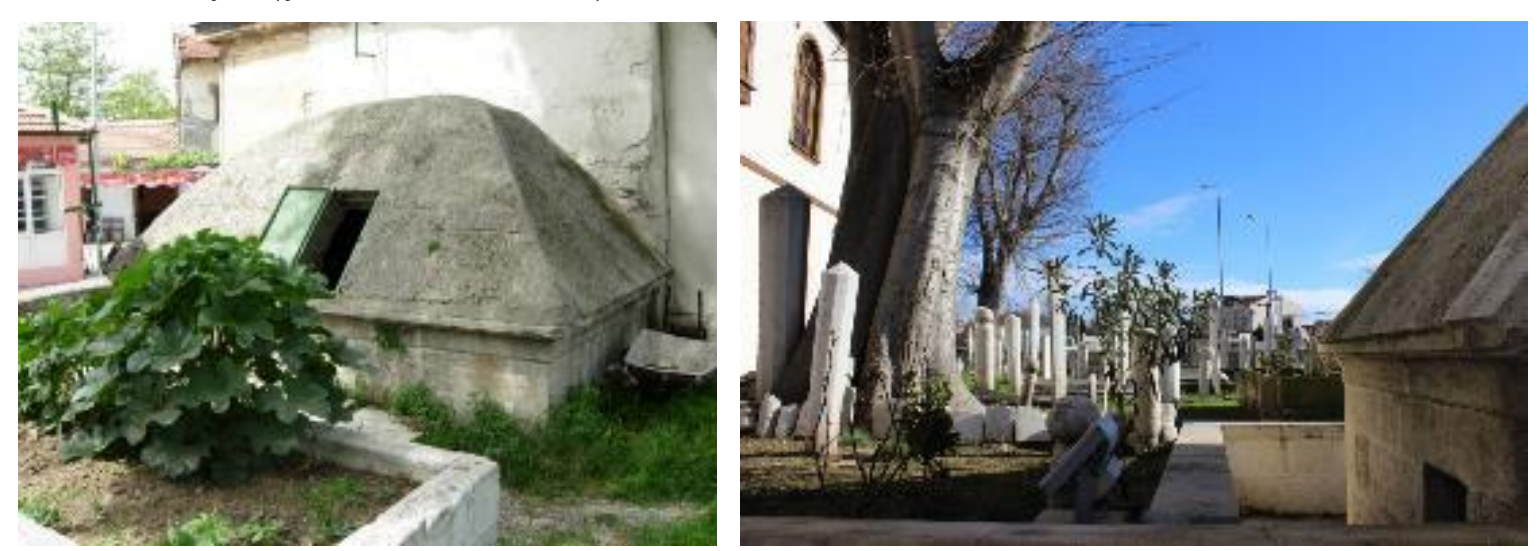

Şekil 15. Çeşme (Edirne V.B.M. arşivi-2008)

Şekil 16. Çeşme ve hazireden görünüm (2019) 


\subsection{4. Şadırvan}

Caminin önünde, ahşap direkler tarafından taşınan kiremit kaplı çatıya sahip ongen planlı bir çardak altında konumlanmaktadır. Çardak restorasyon esnasında yapılmıştır (Şekil 17, 18). Doğu yüzünde, Nazira Efendi tarafından kaleme alındığı belirtilen (Akçıl, 2013: 62; Ahmet Badi, 2000: 92) kitabesi görülmektedir (Şekil 19). Kitabesine göre, H. 1164 (M. 1750-51) yılında Mustafa Efendi tarafından yaptırılmıştır (Akçı1, 2013: 62). Kitabenin okunuşu şu şekilde belirtilmektedir:

"Rûm ilinin abrı veli Mustafa el hûr peştevî

Yaptı bu havuzu giderken hacca izzü şan ile

Geldi bâ tevfik Bâri yazdı tarihin nazîr

Oldu ihya tekke-i vâlâ bu şadırvan ile

Sene 1164" (Onur, 1972: 171).

Şadırvanın taş kaide üzerine oturan mermer haznesi, dilimli gövdeye sahiptir. Altta ve üstte profilli silmelerle bezenmiş gövdedeki dilimlerin arasında sütunçeler yer almaktadır. Sütunçeler arasındaki her bir yüzeyde musluk; önünde de beton oturaklar bulunmaktadır. Her bir yüzeydeki muslukların gülbezenk motifi ortasında konumlandığı (Akçı1, 2013: 62) belirtilmesine karşın günümüzde motiflerden iz kalmamıştır. Şadırvanın ortasında mermerden bir çanak yer almaktadır.
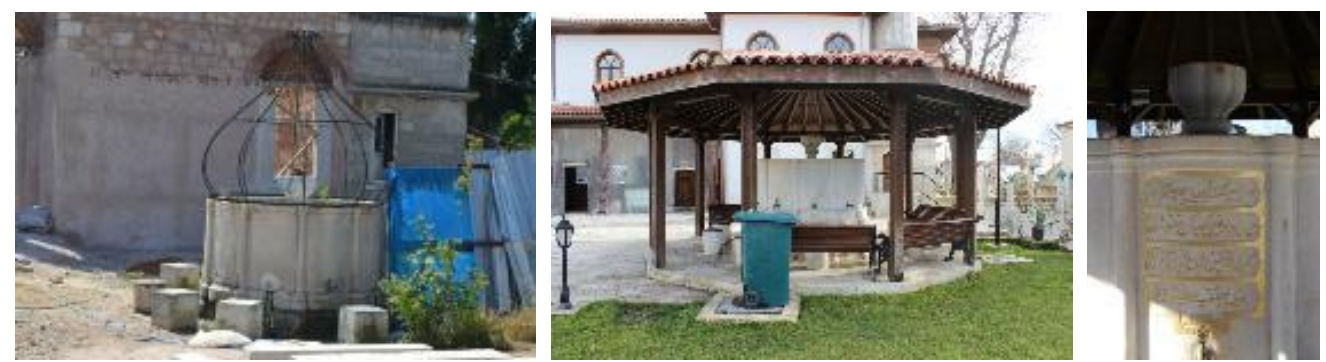

Şekil 17. Restorasyon öncesi şadırvandan görünüm (2014)

Şekil 18. Restorasyon sonrası şadırvandan görünüm (2019)

Şekil 19. Şadırvanın kitabesinden görünüm (2019)

\subsubsection{Hazire ve mezarlar}

Hasan Sezai Türbesi'nin önünde, türbe ile minare arasında kalan alanda, biri İlhami Efendi'ye (Mustafa Paşa soyundan yüksek seyyidlerin başı Ö: 1848), diğeri Edirne Meclisi Reisi Sadrettin Bey'in kızına ait (Çağlarer ve Ek, 2003: 30) olmak üzere iki mezar bulunmaktadır (Şekil 20). La'li Fenayi Efendi'nin türbesinin sol yanında II. Abdülhamid tarafından Edirne'ye sürgün olarak gönderilmiş Kadri Paşa'nın (Cenanizade) (M. 1884/H. 1297) (Tunca, 2003: 27) mezarı (Şekil 21); hazire içinde, çeşmenin yakınında da Hasan Sezai Efendi'nin iki hocasının mezarı yer almaktadir.
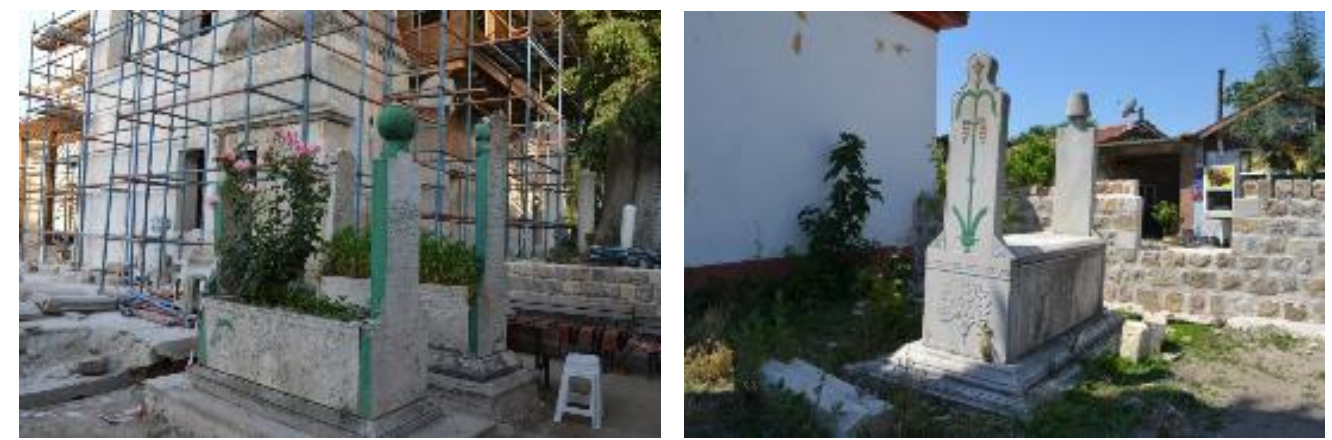

Şekil 20. Hasan Sezai Türbesi'nin önündeki mezarlar (2015)

Şekil 21. Kadri Paşa'nın mezarı (2014)

Turkish Studies, 15(2) 
Hazirede gömülü diğer kişilerin isimleri şunlardır (Çağlarer ve Ek, 2003: 31-48): Sinan Paşa'nın eşi Zeynep Hanım (Ö: 1832), Gülşeni Tekkesi Dervişi (Ö: 1718), Hasan Çelebi Efendi (Ö: 1959), Sadık Efendi (Ö: 1959), Tevhide Hanım (Ö: 1959), Ahmet Efendi oğlu Katipzade Derviş Ağa (Ö: 1812), Şeyh Mahmut Efendi (Ö: 1839), Tuğgeneral Ali Tevfik Paşa'nın eşi Emine Hanım (Ö: 1900), Yüzbaşı Hayri Efendi’nin kızı Hayrünisa Hanım (Ö: 1898), Şeyh Ahmet (Ö: 1903), Abdülhalim Efendi (Ö: 1812), Deviş Hüseyin Baba (Ö: 1844), Lofçalı Ziynet Şakire Hanım (Ö: ?), Muhammed Ali Efendi (Ö: 1910), Osman Nuri Bin Musa (Ö: 1911), Hacı Mustafa İbni merhum Ahmet Gafere (Ö: 1653), Hacı Salih Beyzade Ahmet Bey'in kızı Feriha Hanım (Ö: 1895), Küçük Paşa Muhammet Ağa'nın kızı Şerife Kadire (Ö: 1850), Numan Bey'in eşi Fatıma Hanım (Ö: 1840), Zehra Hanım (Ö: 1755), Mustafa Razi Efendi İbni Muhammed Efendi (Ö: 1857), İbrahim Nesim (Ö: 1827), Defterdar Muhammet Bey'in damadı Nuri Bey'in annesi Ferneke Hanım (Ö: 1896), Topçu Livası Ahmet Paşa'nın eşi Nimetullah Hanım (Ö: 1897), Edirne Defterdarı Müfid Bey’in oğlu Ali Bey (Ö:1 897), Hacı Mustafa (Ö: 1768), Hacı Mustafa Gülşeni (Ö: 1768), Topçu Livası Ahmet Paşa'nın annesi Muhsine Hanım (Ö: 1900), Neşet Bey'in annesi Ayşe Hanım (Ö: 1859), Yusuf Fehmi Bey (Ö: 1908), Haciye Arife Saime Hanım (Ö: 1900), Defter-i Hakan-i Müdürü Müfit Bey (Ö: 1899), Evkaf muhasebecisi Şevki Bey’in annesi Hatice Hanım (Ö: ?).

\subsubsection{Hasan Sezai Camii}

\subsubsection{Tarihçesi}

'Şah Melek Zaviyesi' (Ahmet Badi, 2000: 91) 'Gülşeni, Sezai Dergâhı' (Meriç, 1963: 13), 'Gülşeni, Sezai Tekkesi' (Akçı1, 2013: 56), Aşı1k Musa Dergâhı (Konur, 2009: 80; Özuygun, 1995: 13) adlarıyla da bahsi geçen dergâhın ilk olarak 1428 'de kurulduğ ${ }^{4}$ belirtilmektedir. Badi'nin Hadayik-ül Haikaik Fi Tekmilet-ül Şekayik'ten aktarımına göre, Şah Melek Bey (Ö: 1441) tarafından ahşap çatılı ve tek minareli olarak inşa ettirilen zaviye 'Şah Melek Zaviyesi' adıyla tanınmaktadır. Şeyh Şık Efendi Mısır'dan döndüğünde, burada Gülşeni ayini yapılmaya başlandığı için adı "Gülşeni Tekkesi”" olarak değiştirilmiştir (Ahmet Badi, 2000: 91).

Edirne tekkeleri ${ }^{5}$ üzerine çalışan Akçıl, dergâhın Gülşeniyye tarikatının Sezaiyye kolunun kurucusu Hasan Sezai adına 18. yüzyılın başında, (H. 892) Şah Melek Paşa tarafından 1487'de yaptırılan zaviyenin yerine, inşa ettirildiğinden söz etmektedir (Akçıl, 2009: 81). Araştırmacı bir başka kaynakta ise "Halvetî tarikatının (Gülşenî- Sezaî) koluna bağlı bu tekke, Şah Melek Bey tarafından H. 892/1486 tarihinde camisiyle birlikte inşa edilmiştir" (Akçıl, 2013: 62) ifadesini kullanmıştır. Ayrıca Şah Melek Bey'in ölüm tarihini de H. 845/M. 1441-42 (Akçıl, 2010: 258) olarak belirtmektedir. Bu durum, zaviyenin inşa tarihi konusunda çelişki yaratmaktadır. Aynı zamanda Şah Melek Paşa tarafından, zaviye olarak kullanılan tek bir yapının mı ya da biri tekke diğeri cami olmak üzere iki farklı yapının $\mathrm{m} ı$ inşa ettirildiği anlaşılamamaktadır.

İnşa tarihine ve banisine değinmeyen Tanman, dergâhın ana yapısının mescit olduğunu; çift işleve sahip bu mescidin namaz kılınan bir mekân olarak kullanıldığı gibi tarikat ayinlerinin ve dervişlerin halvet/çile uygulamalarının gerçekleştirildiği bir mekân (tevhithane) olarak da kullanıldığını belirtmektedir. Ayrıca yapının 16. yüzyılda Edirne’ye gelen ve İbrahim Gülşeni’nin halifesi olan Aşık Musa Efendi tarafından 'gülşeni dergâhı' olarak kullanılmaya başlandığından;

\footnotetext{
42012 yılında Edirne Vakıflar Bölge Müdürlüğü arşivinde Hasan Sezai Dergâhı'ndaki yapılara ait bilgileri temin etmemizde bize destek veren dönemin Bölge Müdürü Y. Mimar Hayati Binler’e ve Y. Mimar Barış San'a teşekkür ederiz. Bu bilgiye de dergâhın rekonstrüksiyonuna yönelik hazırlanan 2008 yılı projesindeki rapordan ulaşılmıştır. Ayrıca bkz. (Onur, 1972: 167).

5 "Tekke": Farsça "dayanmak, dayanılan yer" anlamına gelen sözcükten türetilen ve aslı "Tekye" olan bu terim, bir tarikat adına açılan, o tarikata mensup dervişlerin toplanıp zikir ayinlerini yaptıkları yapıya dendiği gibi, dinsel-mistik tarikatlarla ilgili tüm kuruluşlar için de kullanılır. Detaylı bilgi için bkz. (Doğan, 1977: 58)
} 
18. yüzyıl başında da Hasan Sezai Efendi'nin katkılarıyla gülşenilerin merkezi haline getirildiğinden ${ }^{6}$ söz etmektedir.

17. yüzyıldan itibaren birçok onarım gören yapıdan yakın zamana kadar iz kalmamıştır. Badi'nin belirttiğine göre, 17. yüzyılda, Ekmekçizade Ahmet Paşa (ulemadan Fethullah Efendi'nin oğlu, Gülş̧eniliğin ileri gelenlerinden Muhyi Gülşeni'nin kardeşi; Ö: 1618) tarafından onartılan yapı harap olmaya yüz tuttuğu için 1631 (H. 1041) tarihinde İsa Dede adındaki kişi tarafindan yenilenmiştir. 18. yüzyılda, Şeyh Sezai'nin soyundan Sadık Efendi tarafından 1740 (H. 1153) tarihinde temelinden yıktırılan (Ahmet Badi, 2000: 91) tekke yeniden inşa ettirilmiştir. Bu yapıma ilişkin Seyyid Abdullah tarafından kaleme alınmış kitabe (Akçıl, 2013: 64) Hasan Sezai Türbesi'nin batı cephesinde yer almaktadır. Kitabenin okunuşu şu şekilde belirtilmektedir:

"Hâzâ mâkâm-1 kutb-ül-ârifin ve dehâlel vasleyn

Eş̧̧eyh Hasan Sezai kuddise sırr-ül âli

El-ârifü'l kâmi lû'l-mürşidü fi tarikat-1 İbrahimü'l-Gülşeni

Ve benâ beytehü birrü'l-müteberrik sahibü'l-âsar

Ahmet Efendi

Sene 1153" (Onur, 1972: 169).

Dönem şairlerinden Örfi Ağa da bu husustaki şiirinde,

"Görünce Örfî dedi pâk tarih

Yapıldı ehl-i zikru'llah içün câ 1153" (Ahmet Badi, 2014: 169) ifadesiyle H. 1153 (M. 1740-41) tarihini vermiştir.

Kapıs1 üzerinde 1751 tarihinin bulunduğunu; bu nedenle kısa süre sonra tekrar onarılmış olduğunu ifade eden Badi, cami önündeki şadırvanın da 1751'de Peşteli Mustafa Efendi tarafından yaptırıldığını belirtmektedir (Ahmet Badi, 2000: 91).

2006'da yapılan kazı çalışmalarına ait rapor incelendiğinde ise yapıda üç evre tespit edildiği görülmektedir: Birinci evre 1428, ikinci evre yaklaşık 1600'lerin başı, üçüncü evre 1740 y1lına tarihlendirilmiştir?

Birçok onarım geçiren yapı (Şekil 22), 1953 yılındaki depremde tamamen yıkılmış; sadece minaresinin şerefeye kadar olan bölümü ayakta kalmış ve sonrasında sadece minaresi onarılmıştır ${ }^{8}$. Mescit ve tevhithane olmak üzere çift işleve sahip olduğu belirtilen yapının ${ }^{9}$ izleri, 2006-2007 yılları arasında yapılan kazı çalışmaları sonucunda ortaya çıkarılmış (Şekil 23); cami olarak rekonstrüksiyonu 2015 (11 Aralık 2015) yılında tamamlanmıştır.

\footnotetext{
${ }^{6} \mathrm{Bu}$ bilgiye Edirne Vakıflar Bölge Müdürlüğü arşivindeki Hasan Sezai Dergâhı'nın rekonstrüksiyonuna yönelik hazırlanan 2008 yılı projesindeki rölöve raporundan ve aynı dosyada M. Baha Tanman tarafindan hazırlanan "Edirne Hasan Sezaî Dergâhı'nın Mescit-Tevhidhanesinin Rekonstrüksiyonuna İlişkin Rapor"dan ulaşılmıştır.

7 Bu bilgiye Edirne Vakıflar Bölge Müdürlüğü arşivindeki Hasan Sezii Dergâhı'nın rekonstrüksiyonuna yönelik hazırlanan 2008 yılı projesindeki restitüsyon raporundan ulaşılmıştır.

${ }^{8}$ Bu bilgiye Edirne Vakıflar Bölge Müdürlüğü arşivindeki “Edirne-Merkez Hasan Sezai Baba Mescit ve Türbesi” başlıklı genel bilgi notundan ulaşılmıştır.

$9 \mathrm{Bu}$ bilgiye Edirne Vakıflar Bölge Müdürlüğü arşivindeki Hasan Sezai Dergâhı'nın rekonstrüksiyonuna yönelik hazırlanan 2008 yılı projesi kapsamında M. Baha Tanman tarafından hazırlanan “Edirne Hasan Sezaî Dergâhı'nın Mescit-Tevhidhanesinin Rekonstrüksiyonuna İlişkin Rapor"dan ulaşılmıştır.
} 

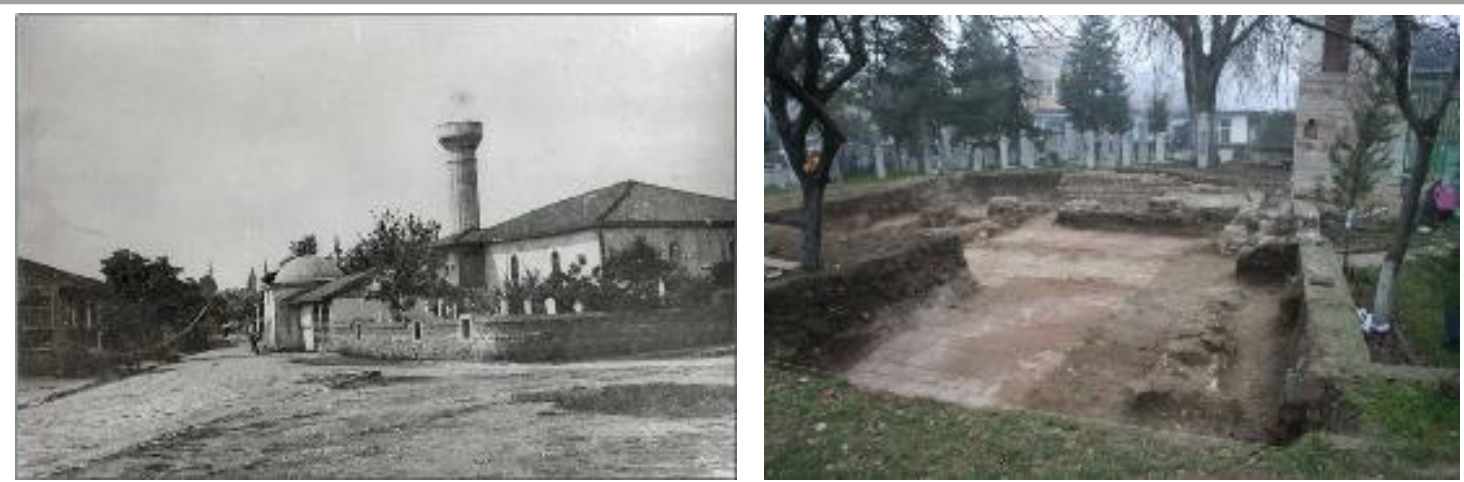

Şekil 22. 1900'lerin başında Hasan Sezai Camii (Edirne V.B.M. arşivi)

Şekil 23. Kazı çalışmalarında ortaya çıkarılan izler (Edirne V.B.M. arşivi-2006)

\subsubsection{Mimari Özellikleri}

Plan Özellikleri: İki katlı yapı, dikdörtgen planlı olup yaklaşık 16x19 metre ölçülerindedir. Yapının merkezinde, dikdörtgen planlı galeri boşluğu yer almaktadır. Galeri boşluğu iki kat halinde yükselen ondört ahşap dikme tarafından sınırlandırılmıştır. Galeri boşluğunu dört taraftan çevreleyen ve ahşap dikmelere uzanan galeriler katları birbirinden ayırmaktadır (Şekil 24, 25, 26).
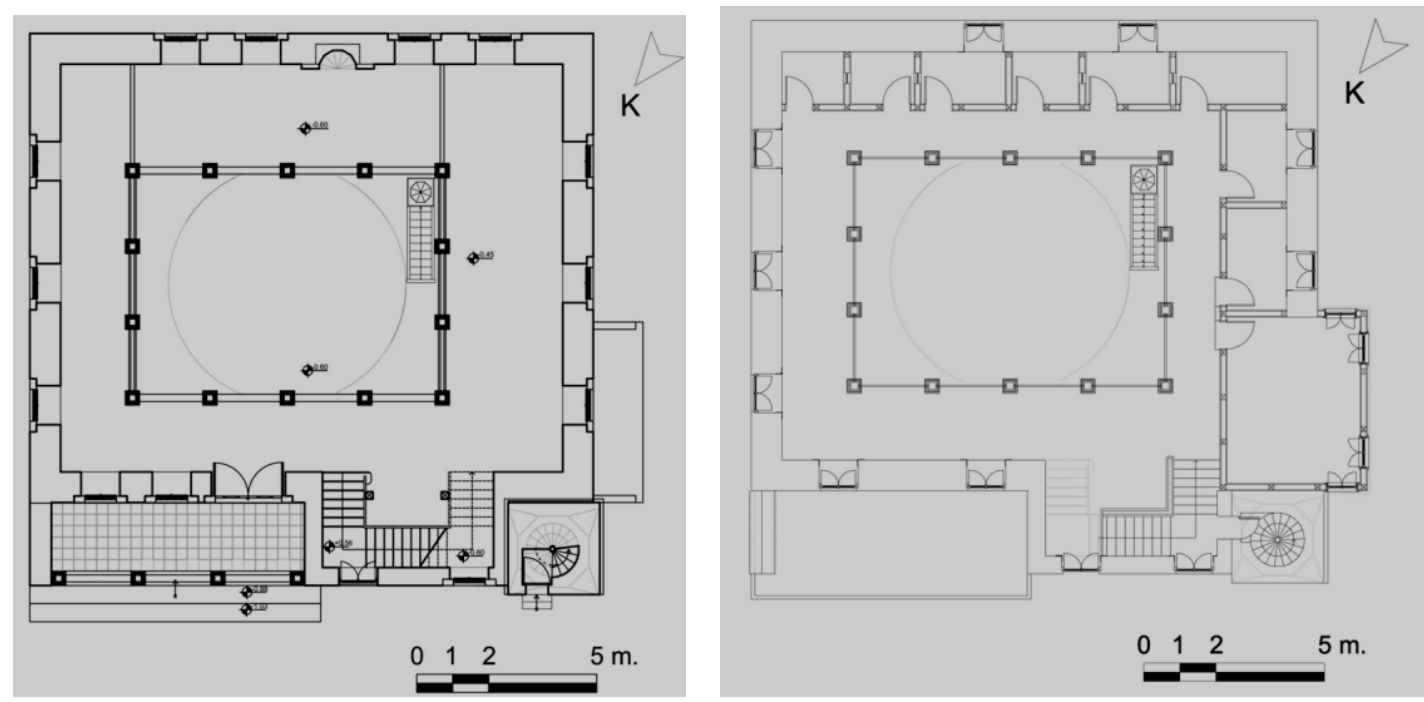

Şekil 24. Caminin zemin kat planı (Edirne V.B.M. arşivi)

Şekil 25. Caminin birinci kat planı (Edirne V.B.M. arşivi)

Yapıya giriş, zemin kattan, kuzeybatı duvarındaki lentolu, iki kanatlı kapıdan sağlanmaktadır. Giriş kapısının yanında (batı yönünde) minare giriş kapısına ve birinci kata ulaştıran ahşap merdiven konumlanmaktadır (Şekil 27). Bu merdiven giriş kapısı hizasından 2.30 metre dişa taşkın olarak yapılmıştır. Güneydoğu duvarının ortasında ahşap kaplı mihrap nişi, mihrabın sağında ahşap minber, solunda ise ahşap vaaz kürsüsü yer almaktadır (Şekil 28). 

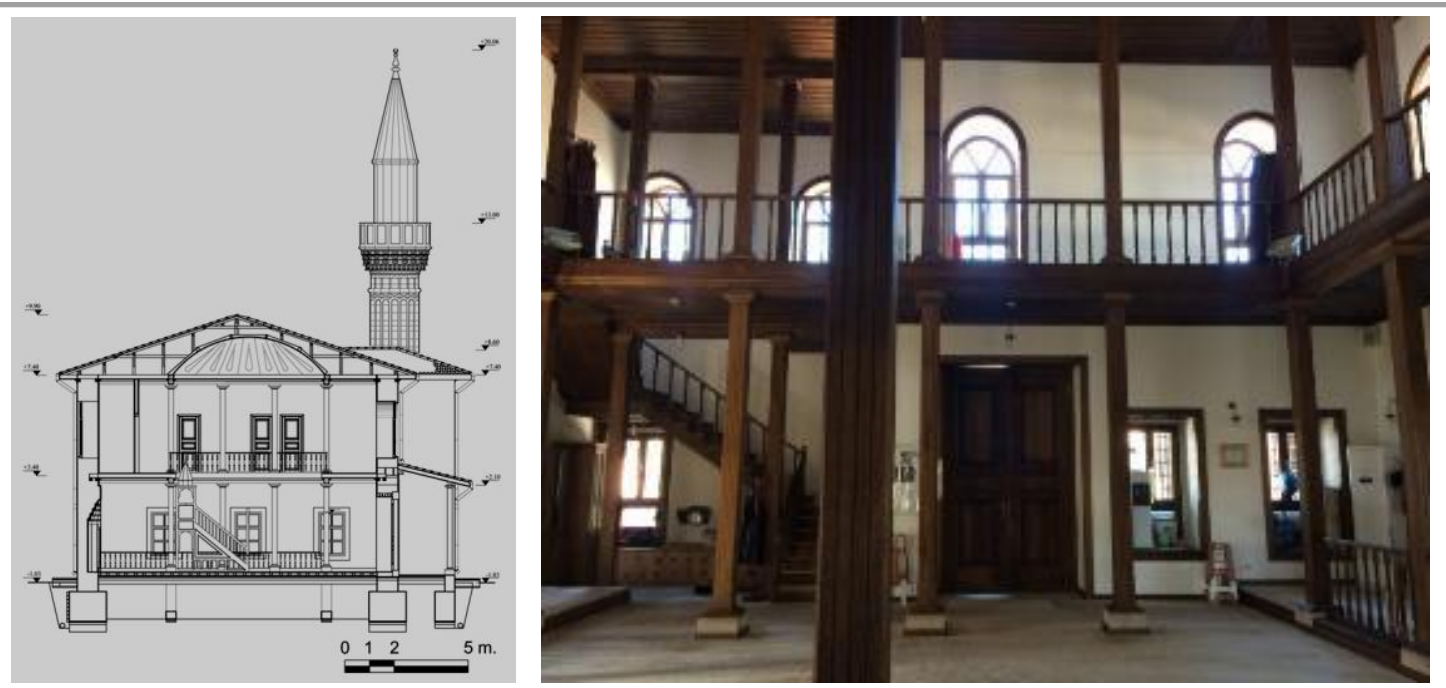

Şekil 26. Cami kesiti (Edirne V.B.M. arşivi)

Şekil 27. Harim kuzeybatı duvarından ve merdivenden görünüm (2019)
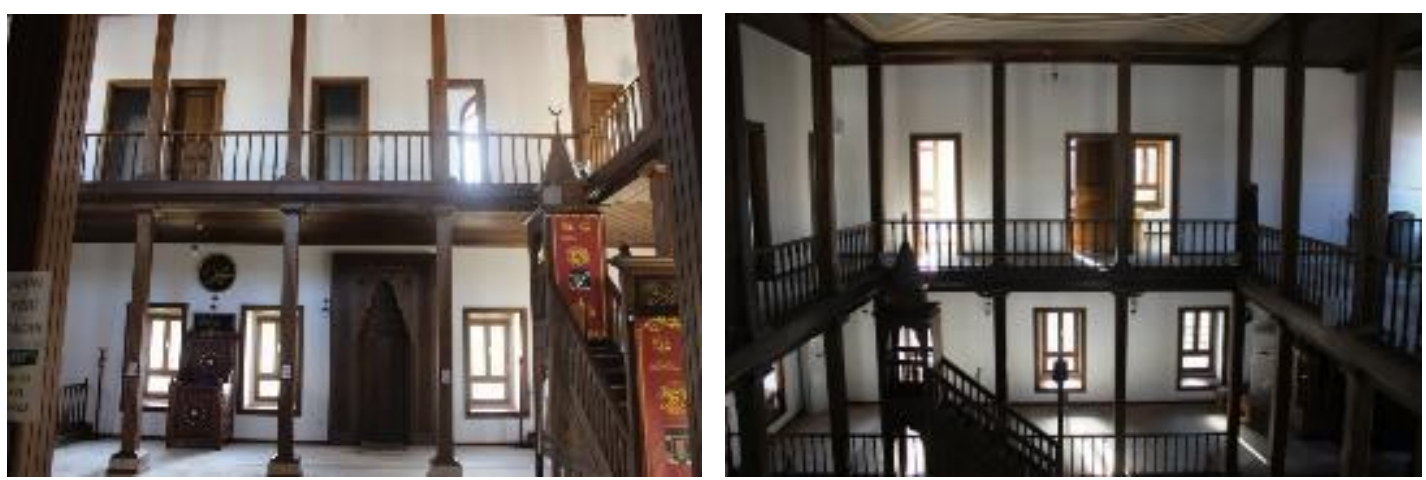

Şekil 28. Mihrap, minber ve vaaz kürsüsünden görünüm (2019)

Şekil 29. Harim güneybatı duvarından ve galeri boşluğundan görünüm (2019)

Birinci katta, yapının merkezindeki galeri boşluğunu dört taraftan saran galeriler ile güneydoğu ve güneybatı kanadındaki galerilerin gerisinde odalar bulunmaktadır. Güneybatı kanadında üç (Şekil 29), güneydoğu kanadında altı oda mevcuttur. Güneybatı kanadında yer alan üç kapıdan ikisi küçük odalara; biri (güneybatı kanadının batı ucuna yakın olan) büyük odaya açılmaktadır. Büyük oda, güneybatı cephesinden ve minarenin yanından konsol çıkılarak oluşturulmuştur. Güneydoğu kanadında yer alan farklı büyüklükteki odalara ise galerilere açılan kapılardan ulaşım sağlanmaktadır. Ayrıca güneydoğu kanadında -ortadaki iki oda hariç- diğer odalar içeriden de birer kapı (güney yönündeki köşe oda da kapı yerine pencere açıklığı mevcut) ile birbirine bağlantılıdır. Bu durum her odada pencere olmadığından mekânların aydınlatma sorununun çözümü olarak değerlendirilebilir.

Caminin önünde -kuzeybatı cephesinin ortasına kadar uzanan- üç gözlü bir son cemaat yeri yer almaktadır. Kuzeybatı cephesinin batı ucunda da tek şerefeli bir minare konumlanmaktadır.

Cephe Özellikleri: Yapının tüm cepheleri sıvalı ve beyaz badanalı olup iki sıralı pencere düzenine sahiptir (Şekil 30, 31). Kuzeydoğu cephede altta üç, üstte üç; güneydoğu cephede altta dört, üstte üç; güneybatı cephede altta üç, üstte dört pencere görülmektedir. Güneybatı cephedeki üst pencerelerden ikisi, cephenin batı ucunun üst yarısında konumlanan, cumba şeklindeki çıkmada yer almaktadır. Çıkma yüzeyi ahşap kaplıdır. Çıkmanın solunda minare görülmektedir. Kuzeybatı cephede ise altta üç, üstte dört pencere görülmektedir. Alt pencerelerden biri ile üst pencerelerden ikisi cepheden dışa taşan merdiven holünde yer almaktadır. Cephenin batı ucu minare ile 
sonlanmakta ve minarenin arkasından üst kattan konsol çıkan ve güneybatı yönünde uzanan çıkmaya ait bir pencere görülmektedir. Merdiven holünün solunda, ahşap direkler tarafından taşınan kiremit kaplı sundurma çatı ile örtülü son cemaat yeri konumlanmaktadır. Çatının eğimi cephenin yarı yüksekliğinden başlamaktadır. Son cemaat yeri kuzey uçta bir duvarla sonlanmakta ve duvarın çatı eğimine uygun olarak yükseldiği görülmektedir. Yapının dikdörtgen formda, lentolu, iki kanatlı giriş kapısı merdiven holünün solunda konumlanmakta ve bu kapıya son cemaat yerinden geçilerek ulaşılmaktadır.
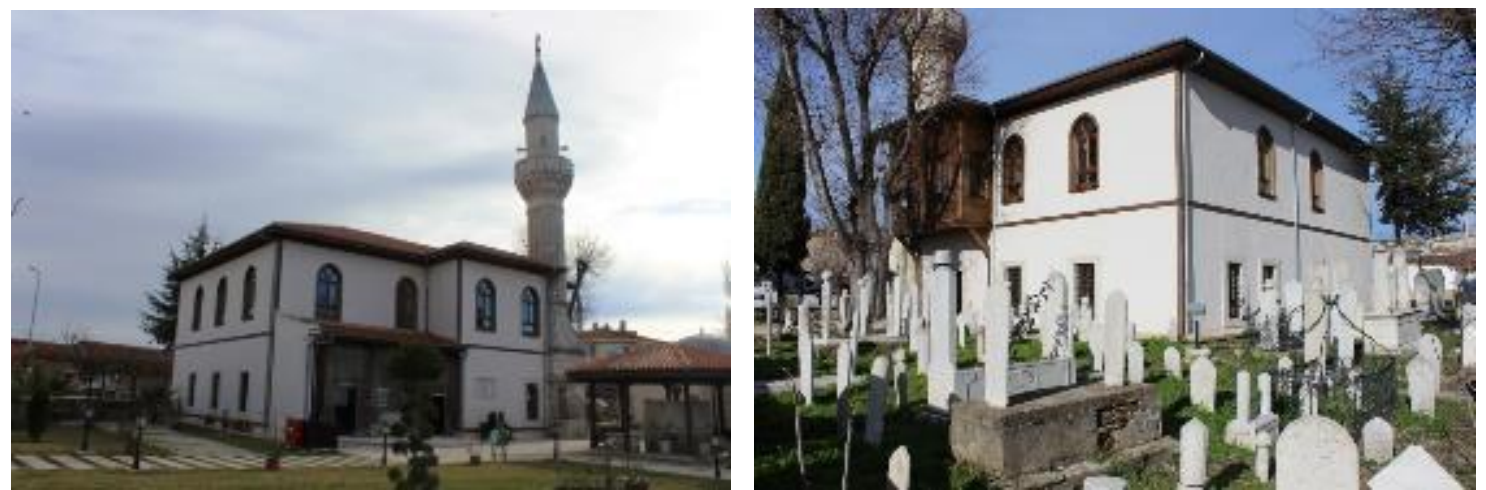

Şekil 30. Caminin kuzeyden görünümü (2019)

Şekil 31. Caminin ve hazirenin güneyden görünümü (2019)

Tüm cephelerdeki alt pencereler ile cumba şeklindeki konsol çıkmanın pencereleri dikdörtgen forma sahiptir. Alt pencereler lentolu, taş söveli, demir parmaklıklı; üst pencereler cumba şeklindeki konsol çıkmanın pencereleri hariç- yarım daire kemerli ve ahşap sövelidir. Yapının üzeri üzeri kiremit kaplı, geniş saçaklı, kırma çatı ile örtülüdür.

Yapım Tekniği ve Malzeme Özellikleri: Yı̆̆ma sistemde inşa edilen yapının duvarları, tuğla hatıllı kabayonu taştır (Şekil 32). Beden duvarlarında nadiren düzgün kesme taş kullanılmıştır. Kemerler tuğladan örülmüş̧ür. Kemer aynaları tuğla dolguludur. Alt sıra pencereler taş söveli ve lentoludur. Beden duvarlarına içten ve dıştan çimento harçlı sıva uygulanmıştır.

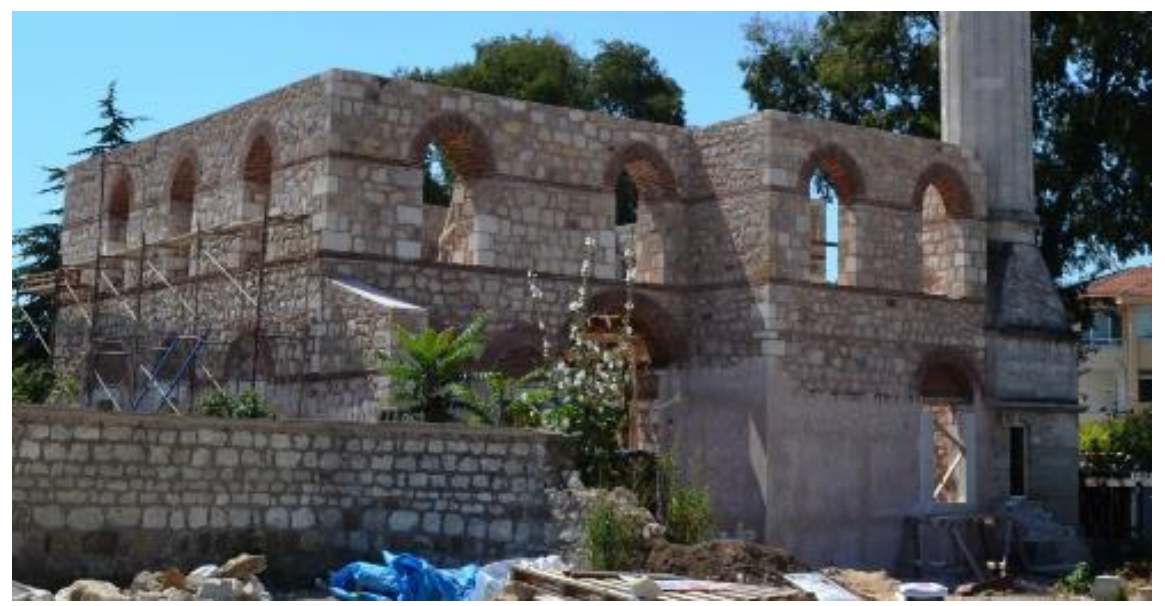

Şekil 32. Caminin kuzeyden görünümü (2014)

İç mekânda, mihrap nişi çimento harçlı sıva ile sıvanmış ve ahşap kaplanmıştır. Dört yönde uzanan ve aynı zamanda katları ayıran galeriler ahşap konstrüksiyonludur. Galerilerin ahşap döşemesini ahşap kirişler ile taş kaidelere oturan on dört ahşap direk taşımaktadır. Galerilere, minare giriş kapısına ve birinci kata çıkışı sağlayan merdiven ahşap konstrüksiyonludur (Şekil 27, 33). Galeriler gibi birinci kattaki odaların döşemesi de ahşaptır. Güneybatı yönündeki büyük oda, ahşap konsolla cepheden dişa uzanmaktadır (Şekil 34, 35). 

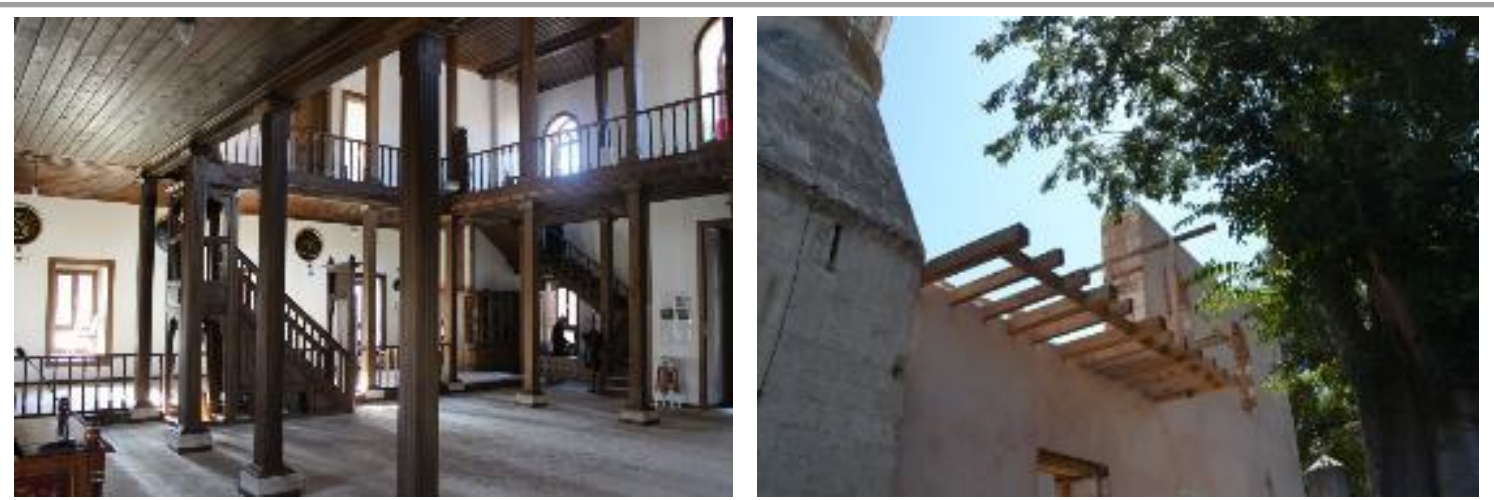

Şekil 33. Galerileri taşıyan ahşap direklerden ve ahşap merdivenden görünüm (2019)

Şekil 34. Caminin güneybatı cephesindeki konsoldan görünüm (2014)

Yapının üstü içte, kubbe ve düz ahşap tavan ile; dışta, kiremit kaplı kırma çatı ile örtülüdür. Kubbe yapının merkezini, bir diğer ifade ile galeri boşluğunu örtmektedir. Ahşap konstrüksiyonlu kubbe ahşap direklerle taşınmaktadır. Kırma çatı ise yapının beden duvarlarına oturmaktadır.

Minaresi: Kesme taştan inşa edilmiş minarenin kare planlı kaidesinin kuzeybatı cephesinde dışarıdan minareye girişi sağlayan bir kapı yer almaktadır. Pabuç bölümü -doğu köşesi hariçpahlıdır. Dairesel planlı gövdenin alt ve üst bölümünde bilezik şeklindeki iki silme bulunmaktadır. $\mathrm{Bu}$ iki bileziğin arasında altta ve üstte birleşen yarı silindirik profillerle gövdeye çokgen yüzeyli görünüm kazandırılmıştır. Üst bileziğin altında, yarı silindirik bezemelerin üstünde ise baklava desenleri yer almaktadır. Gövdeden şerefeye beş sıra mukarnastan oluşan konsolla geçilmiştir. Oldukça sade görünümlü şerefe korkuluğunun her bir yüzeyi kapalıdır. Gövdedeki süsleme petek bölümünde de yinelenmiştir. Minarenin üstü kurşun kaplı sivri külah ile örtülüdür (Şekil 35).
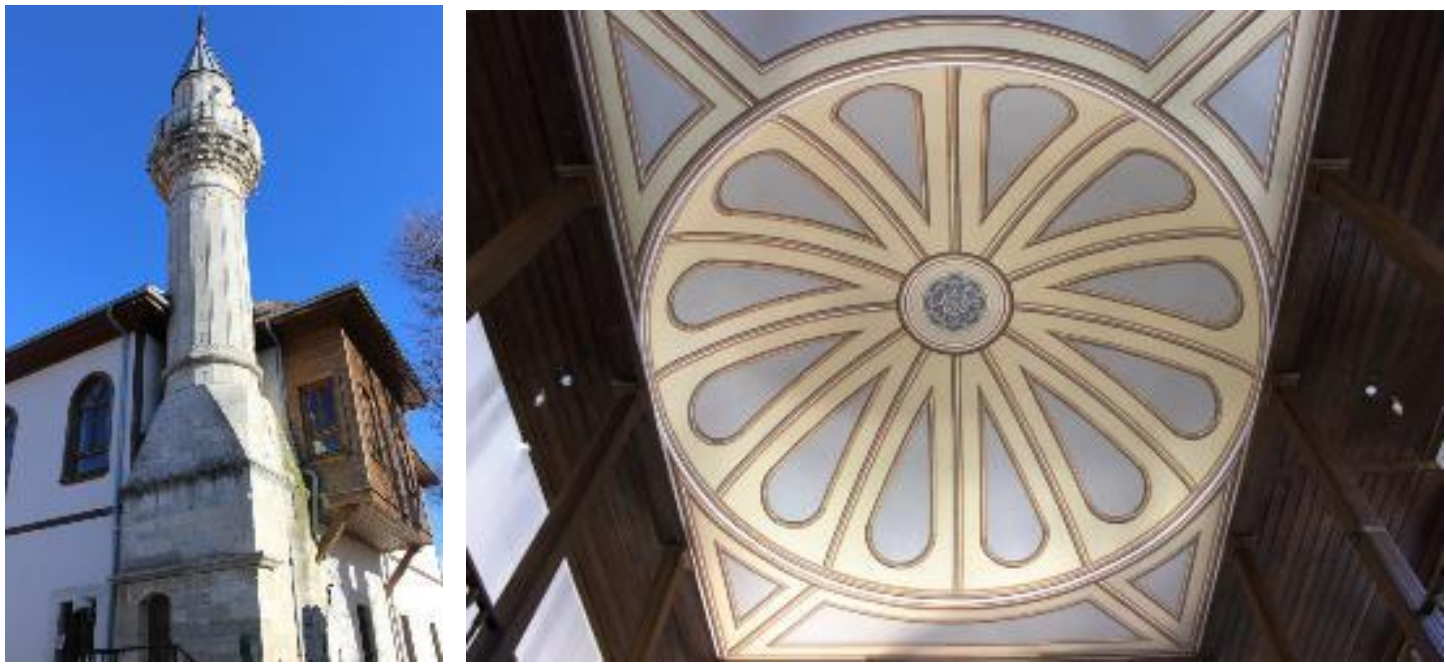

Şekil 35. Caminin güneybatı cephesindeki konsoldan ve minareden görünüm (2019)

Şekil 36. Kubbe bezemesinden görünüm (2019)

Süsleme Özellikleri: Yapıdaki tek süsleme galeri boşluğunu örten kubbede görülmektedir. Kubbenin ortasında siyah, beyaz ve gri renklerinden ibaret, $\mathrm{S}$ ve $\mathrm{C}$ kıvrımlarından oluşan, yaprak motiflerini çağrıştıran bir süsleme motifi yer almakta ve bu motifi beyaz, bej, açık ve koyu kahverenginde halkalar kuşatmaktadır. En dış halkadan eteğe yayılan 1şınsal çizgilerle kubbe dilimlere ayrılarak her bir dilimin içine damla motifi yerleştirilmiştir. İçi gri renkli damla motifi de ortada beyaz, iki yanda açık kahverenginde çizgilerle sınırlandırılmış; koyu kahverengi çizgilerle de gölge etkisi yaratılmıştır (Şekil 36). 


\section{Değerlendirme ve Sonuç}

Osmanlı Dönemi'nde 15. yüzyıldan itibaren cami-tevhithane ile birlikte türbe, kitaplık, çeşme, şadırvan ve dergâh evi gibi yapıların inşa edildiği görülmektedir (Tanman, 1990: 141-250; Demirel İşli, 1998: 176-196). Merkezinde caminin bulunduğu külliyeleri anımsatan bu yapılardan biri Hasan Sezai Dergâhı olup Tablo 1'de verilen yapı örneklerinin de Hasan Sezai Dergâhı ile benzer nitelikte olduğu söylenebilir.

Tablo 1. Yapılar Topluluğundan Oluşan Tekke ve Dergâh Örnekleri

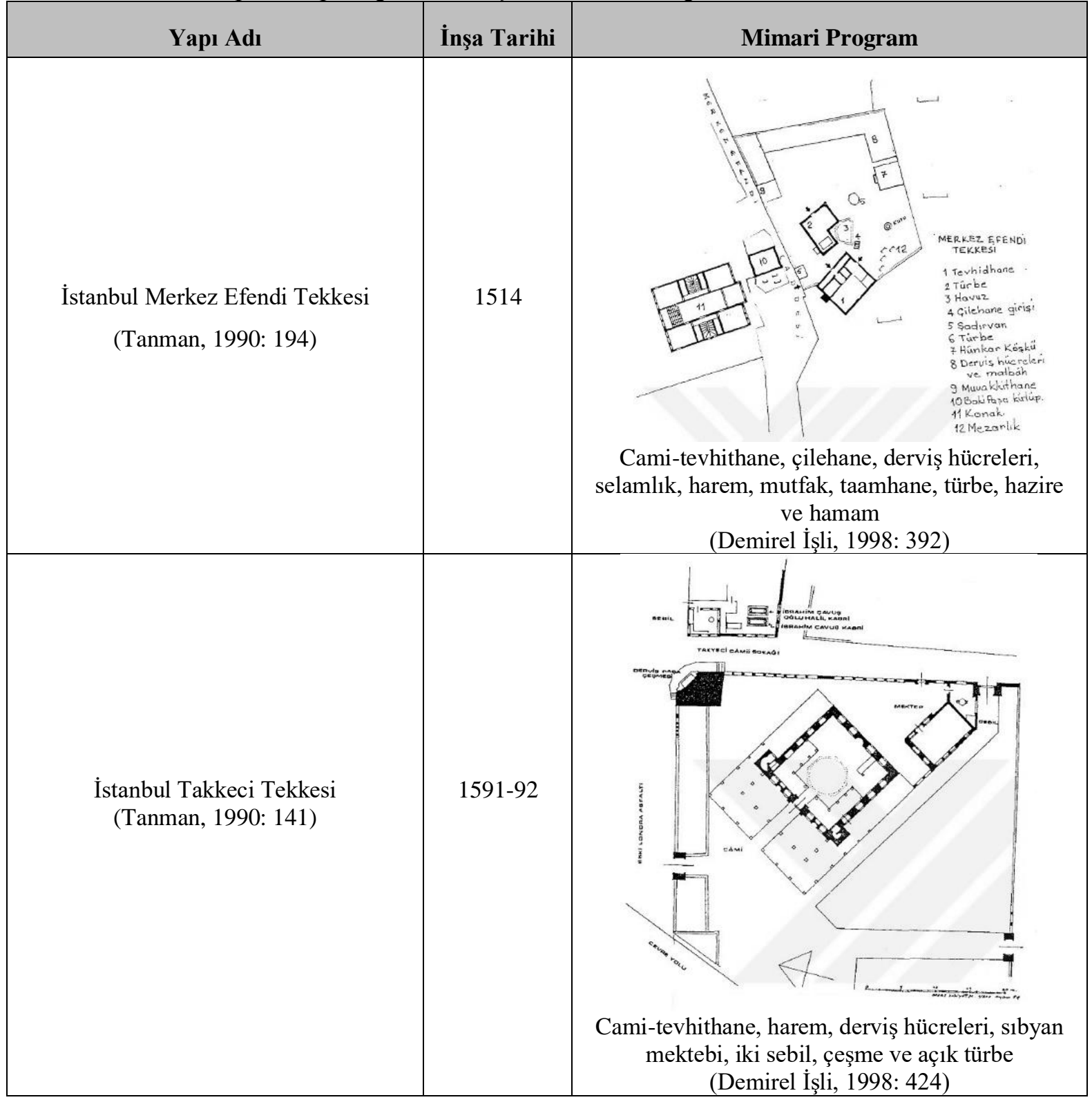




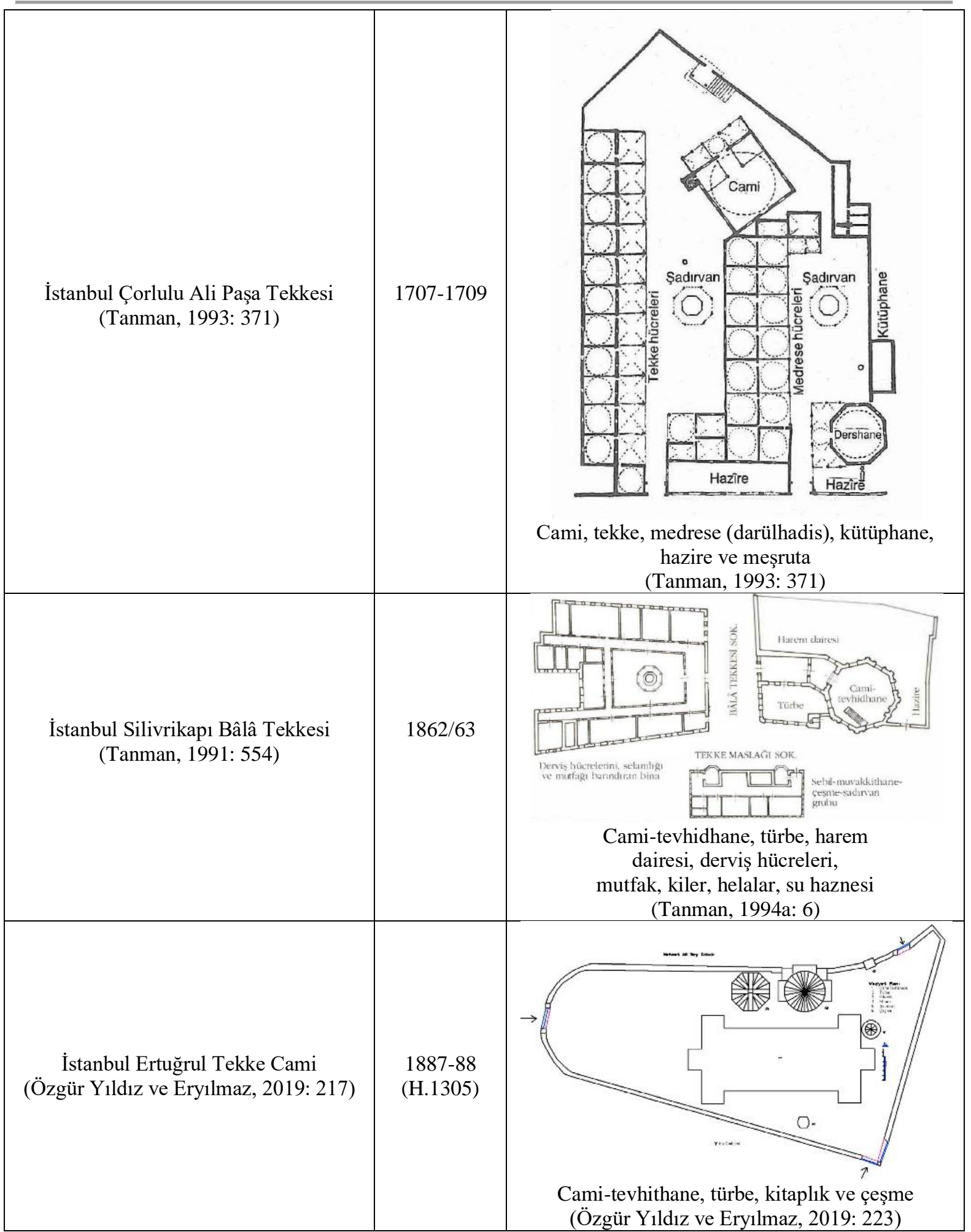

Hasan Sezai Camii, cami-tevhithane niteliğinde bir yapıdır. Cami-tevhithane yapıları hem ibadet hem de ayinlerin gerçekleştirilmesine olanak verecek şekilde tasarlanmışlardır. $\mathrm{Bu}$ doğrultuda incelenen yapıda olduğu gibi Tablo 2'de verilen örneklerde de benzer bir işlevsel kurgu söz konusudur. 
Edirne Hasan Sezai Dergâhı Üzerine Bir İnceleme

Tablo 2. Cami-Tevhithane Niteliğindeki Yapı Örnekleri

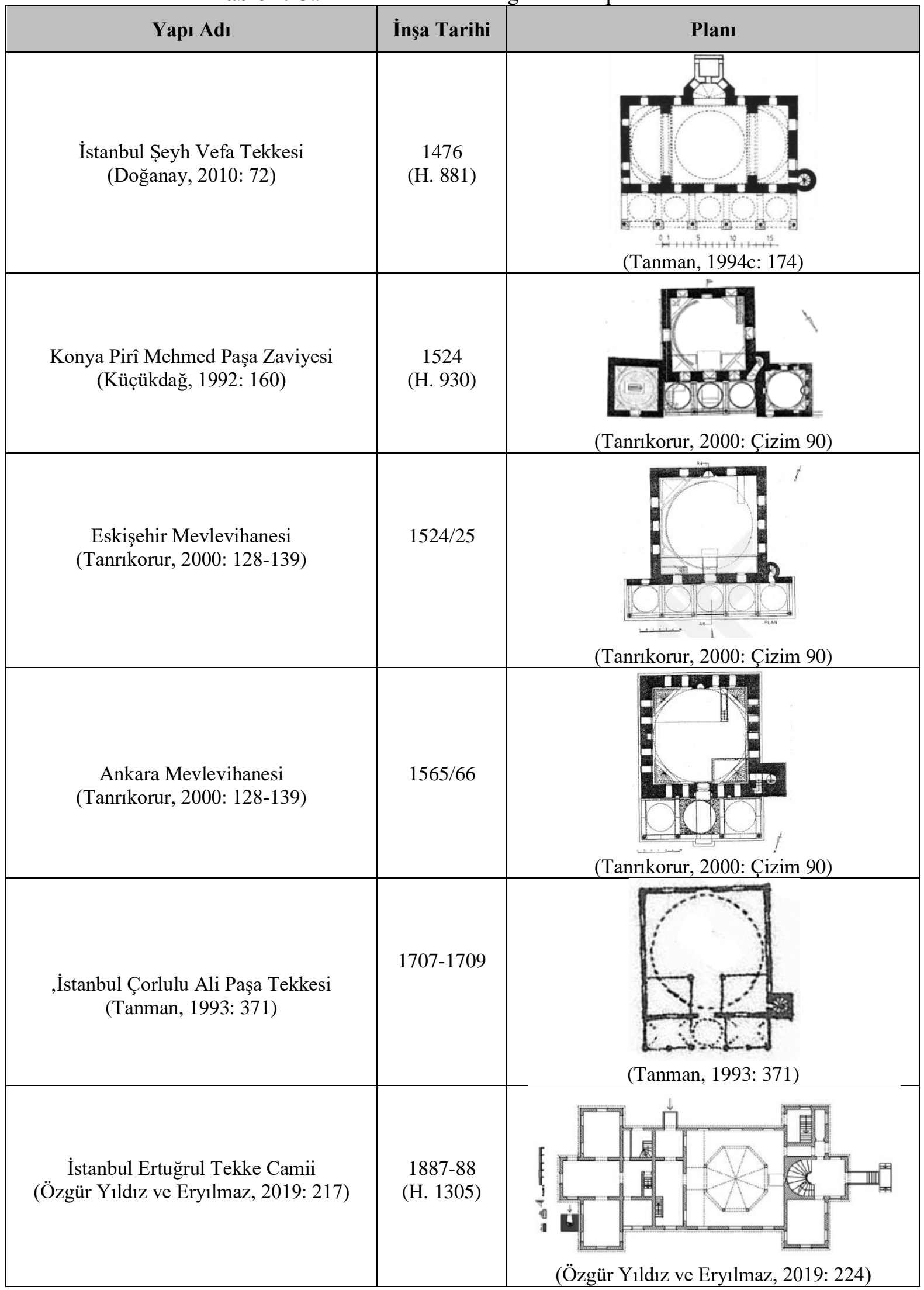


Üst örtü açısından incelendiğinde, Hasan Sezai Camii’nde olduğu gibi, Osmanlı kaynaklarında 'çârpuşta kubbe' olarak adlandırılan, çatı altında gizlenmiş, ahşap iskeletli kubbelere rastlanır (Tanman, 2014: 77). Söz konusu uygulama tekke olarak tasarlanan ve Tablo 3 'te belirtilen yapılarda da izlenmektedir. Ayrıca Hasan Sezai Camii'nin kubbesi ahşap direkler tarafından taşınmaktadır. Benzer yapım tekniği Tablo 4'te verilen yapılarda da görülmektedir.

Tablo 3. Çârpuşta Kubbe Görülen Yapı Örnekleri

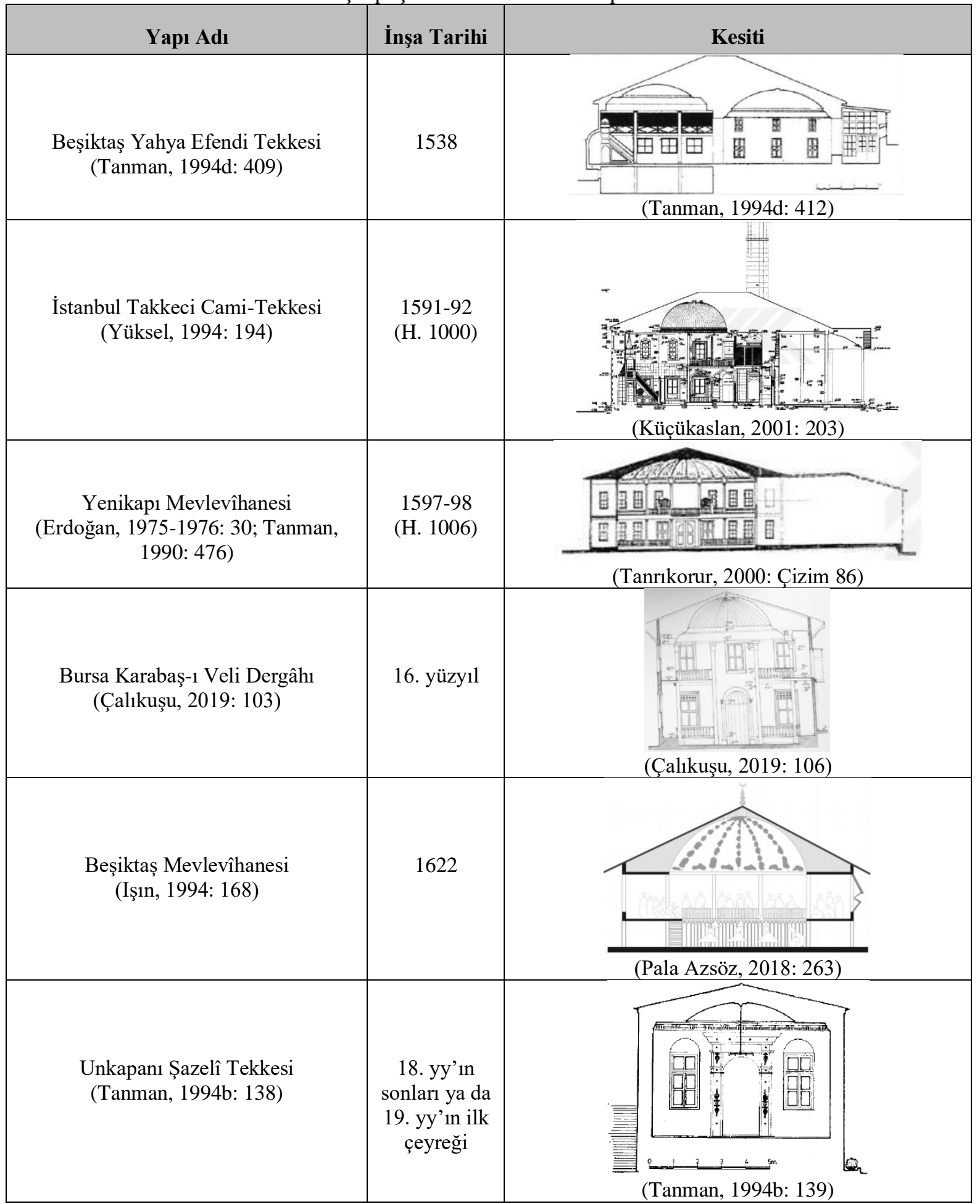

Turkish Studies, 15(2) 


\begin{tabular}{|c|c|c|}
\hline \multicolumn{2}{|c|}{ Tablo 4. Kubbesi Ahşap Direkler Tarafından Taşınan Tekke ve Dergâh Örnekleri } \\
\hline Yapı Adı & İnşa Tarihi & \\
\hline $\begin{array}{c}\text { Beşiktaş Yahya Efendi Tekkesi } \\
\text { (Tanman, 1994d: 409) }\end{array}$ & 1538 & Kubbe Taşıyıcıları \\
\hline $\begin{array}{c}\text { Bursa Karabaş-1 Veli Dergâhı } \\
\text { (Çalıkuşu, 2019: 103) }\end{array}$ & 16. yüzyıl & \\
\hline
\end{tabular}

Süsleme açısından ele alındığında ise Hasan Sezai Camii harim kubbesinin yüzeyinde çıtalarla, merkezdeki dairesel göbekten dağılan, on iki dilimli ışınsal bir taksimat yapılmıştır. Doğu ve batı yönlerinde dikdörtgenle kubbenin eteği arasında kalan yüzeyler yine çıtalarla yapılan üçgen bir taksimatla bezenmiştir. Söz konusu işınsal bezemenin benzeri, kıyaslama yapılan örnekler arasında, Yenikapı Mevlevîhanesi'nin semahanesini taçlandıran -çıtalarla yirmi dört dilime ayrılmış- kubbede (Tanman, 1990: 437) yer almaktadır (Şekil 37).

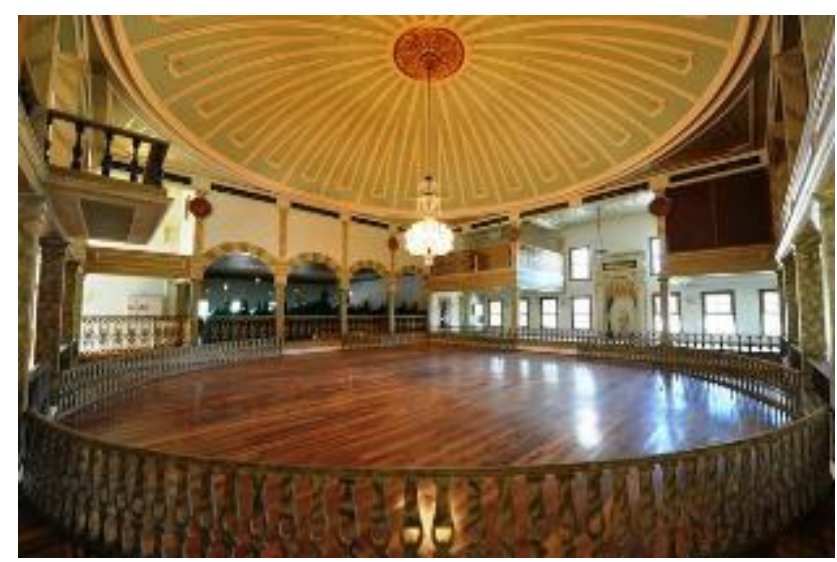

Şekil 37. Yenikapı Mevlevîhanesi’ndeki Semahanenin kubbesi

(http://www.zeytinburnu.istanbul/Haberler/Kultur-Abidesi-Yenikapi-Mevlevihanesi) 
Sonuç olarak, Osmanlı Dönemi’nde yaygınlık kazanan tarikatlar tarafından birçok dergâh kurulmuştur. Bu dergâhlardan biri olan Hasan Sezaî Dergâhı da Edirne'nin kültür ve tasavvufî hayatında önemli bir yere sahip olmuştur. Dergâh, Halveti-Gülşeni tarikatının Hasan Sezai Efendi tarafindan tesis edilen ve Sezai'ye nispet ile 'Sezaiyye' adı verilen kolunu temsil etmiştir. Sezaiyye, 20. yüzyıl başına kadar, Edirne'deki Gülşeni tarikatını temsil eden kol olmuştur.

Hasan Sezaî Dergâhı'nın 15. yüzyıldan itibaren inşasına başlanan tekke ve zaviye gibi benzer nitelikteki yapılar arasında külliye özelliği sergilemesi ve camisinin bir tevhithane işlevine sahip olması açısından da önem taşıdığı görülmektedir. Ayrıca kare ya da dikdörtgen planlı, üzeri kırma çatı ya da kubbe ile örtülü klasik camilerden farklılık gösteren camisinin mimari özellikleri ile de dikkat çektiği söylenebilir.

\section{Kaynakça}

Ahmet Badi. (2000). Riyaz-ı Belde-i Edirne/ Edirne Şehri Bahçeleri (Edirne Şehri Tarihi). Ratıp Kazancıgil (Çev.). Cilt I, İstanbul: Edirne Valiliği Yayını.

Ahmet Badi. (2014). Ahmet Badi Efendi Riyaz-ı Belde-i Edirne/20. Yüzyll'a Kadar Osmanlı Edirne'si. Niyazi Adıgüzel, Raşit Gündoğdu (Haz.). Cilt I, İstanbul: Trakya Üniversitesi Yayını.

Akçı1, N. Ç. (2009). "Sezai-yi Gülşeni Külliyesi”. TDV İslam Ansiklopedisi, 37: 81-82.

Akçı1, N. Ç. (2010). "Şah Melek Camii”. TDV İslam Ansiklopedisi, 38: 257-258.

Akçıl, N. Ç. (2013). Edirne Tekkeleri. İstanbul: Edirne Valiliği Kültür Yayınları.

Canım, R. (2003). “Gülşenilerin Edirne'de Açan Gülü: Sezayi-i Gülşeni”. Yöre Dergisi, 45: 4-8.

Çağlarer, M. C. ve Ek, R. (2003). "Gülşeni Dergâhı Haziresi Mezartaşı Kitabeleri Hakkında”. Yöre Dergisi, 45: 29-48.

Çalıkuşu, E. (2019). Bursa Tekkelerinin Mimari ve Süsleme Özellikleri. Yayımlanmamış doktora tezi, Mimar Sinan Güzel Sanatlar Üniversitesi Sosyal Bilimler Enstitüsü, İstanbul.

Demirel İşli, E. (1998). İstanbul Tekkeleri Mimarisi Eklentileri ve Restorasyonu, Yayımlanmamış doktora tezi, Yıldız Teknik Üniversitesi Sosyal Bilimler Enstitüsü, İstanbul.

Doğan, A. I. (1977). Osmanlı Mimarisinde Tarikat Yapılarl, Tekkeler, Zaviyeler ve Benzer Nitelikli Fütüvvet Yapıları. İstanbul: İ.T.Ü. Mimarlık Mühendislik Fakültesi Matbaası.

Doğanay, A. (2010). "Şeyh Vefa Külliyesi”. TDV İslâm Ansiklopedisi, 39: 72-74.

Edirne Vakıflar Bölge Müdürlüğü arşivi. Hasan Sezai Dergâhı 2008 yılı projesi.

Erdoğan, M. (1975-1976). "Mevlevî Kuruluşları Arasında İstanbul Mevlevîhaneleri”, Güney-Doğu Avrupa Araştırmaları Dergisi, IV-V: 15-46.

Erkurt, M. (2008). "Hasan Sezai Hakkında”. Yöre Dergisi, 97: 33-34.

Gölpınarlı, A. (1969). 100 Soruda Tasavvuf. İstanbul: Gerçek Yayınevi.

Işın, E. (1994). "Beşiktaş Mevlevîhanesi”, Dünden Bugüne İstanbul Ansiklopedisi, 2: 168-171.

Kazancigil, R. ve Gökçe, N. (2005). Dağdevirenzade M. Şevket Bey'in Edirne Tarihi ve Balkan Savaşı Anıları. Edirne: Türk Kütüphaneciler Derneği Edirne Şubesi Yayınları.

Kılıç, R. (2004). “Osmanlı Devleti’nde Gülşenî Tarikatı (Genel Bir Yaklaşım Denemesi)”. Osmanlı Tarihi Araştırma ve Uygulama Merkezi Dergisi OTAM, 15: 209-226.

Konur, H. (2009). “Sezai-yi Gülşeni”. TDV İslam Ansiklopedisi, 37: 79-81. 
Küçükaslan, F. (2001). Takkeci İbrahim Ağa Camii: Teknik Çözümleme ve Çevre Yapılarıya Birlikte Koruma Projesi. Yayımlanmamış yüksek lisans tezi, İstanbul Teknik Üniversitesi Fen Bilimleri Enstitüsü, İstanbul.

Küçükdağ, Y. (1992). "Konya'da Bir Mevlevi Manzumesi (Piri Mehmed Paşa Zaviyesi ve Vakfiyesi)". Vakıf Haftası Dergisi, 9: 159-178.

Meriç, R. M. (1963). Edirne’nin Tarihi ve Mimari Eserleri Hakkında. İstanbul: Berksoy Matbaası.

Ocak, A. Y. (1978). "Zaviyeler (Dini, Sosyal ve Kültürel tarih açısından bir deneme)". Vakıflar Dergisi, XII: 247-269.

Onur, O. (1972). EDIRNE Türk Tarihi Vesikalarından KITABELER. İstanbul: Yenilik Basımevi.

Özgür Yıldız, Ş. ve Eryılmaz, H. İ. (2019). "II. Abdülhamid Eseri: "Ertuğrul Tekke CamiTevhithanesi”. Ordu Üniversitesi Sosyal Bilimler Araştırmaları Dergisi, 9 (1), 215-242.

Özkan, S. (1995). Edirne Türbeleri. Yayınlanmamış yüksek lisans tezi, Trakya Üniversitesi Sosyal Bilimler Enstitüsü, Edirne.

Özuygun, A. R. (1995). Hasan Sezayi-i Gülşeni. Edirne: Hasan Sezai Teknik İlim ve İrfan Vakfı Yayın1, Erkam Matbaas1.

Pala Azsöz, G. (2018). İstanbul Mevlevîhânelerinde Mimari Düzen ve Beşiktaş Mevlevîhânesi. Yayımlanmamış doktora tezi, Yıldız Teknik Üniversitesi Fen Bilimleri Enstitüsü, İstanbul.

Şimşek, S. (2008). Osmanlı'nın İkinci Başkenti Edirne'de Tasavvuf Kültürü. İstanbul: Buhara Yayınları.

Tanman, M. B. (1990). İstanbul Tekkelerinin Mimari ve Süsleme Özellikleri Tipoloji Denemeleri, (Cilt. 2). Yayımlanmamış doktora tezi, İstanbul Üniversitesi, Sosyal Bilimler Enstitüsü, İstanbul.

Tanman, M. B. (1991). "Bala Külliyesi”. TDV İslâm Ansiklopedisi, 4: 554-556.

Tanman, M. B. (1993). "Çorlulu Ali Paşa Külliyesi”. TDV İslâm Ansiklopedisi, 8: 371-373.

Tanman, M. B. (1994a). "Şazelî Tekkesi”. Dünden Bugüne İstanbul Ansiklopedisi, 7: 138-139.

Tanman, M. B. (1994b). "Yahya Efendi Tekkesi”. Dünden Bugüne İstanbul Ansiklopedisi, 7: 409412.

Tanman, M. B. (1994c). "Şeyh Vefa Külliyesi”. Dünden Bugüne İstanbul Ansiklopedisi, 7: 173176.

Tanman, M. B. (1994d). "Yahya Efendi Tekkesi”. Dünden Bugüne İstanbul Ansiklopedisi, 7: 409412.

Tanman, M. B. (2009). “Edirne Hasan Sezaî Dergâhı'nın Mescit-Tevhidhanesinin Rekonstrüksiyonuna İlişskin Rapor”. Edirne Vakıflar Bölge Müdürlüğü Arşivi.

Tanman, M. B. (2013). "Yahya Efendi Külliyesi”. TDV Íslam Ansiklopedisi, 43: 246-249.

Tanman, M. B. (2104). “Ortaköy’ün Osmanlı Döneminde Gelişimi ve Mimari Eserleri”. Büyük Mecidiye Camii ve Ortaköy. (Ed.) Mehmet Baha Tanman. İstanbul: Kuveyt Türk Katılım Bankası Kültür Yayınları. 63-119.

Tanrıkorur, Ş. B. (2000). Türkiye Mevlevîhanelerinin Mimarî Özellikleri. Yayımlanmamış doktora tezi, Selçuk Üniversitesi Sosyal Bilimler Enstitüsü, Konya.

Tunca, A. (2003). "Edirne Valilerinden Kadri Paşa'nın Mezarı ve Paşa Hakkında”. Yöre Dergisi, 45: $27-28$.

www.turkishstudies.net/turkishstudies 
Uludağ, S. (1997). "Hankah”. TDV İslam Ansiklopedisi, 16: $42-43$.

Yazıcı, T. (1966). "Seza'i, Saza'i, Hasan B. Ali Gülşeni”. İslâm Ansiklopedisi-İslâm Âlemi Tarih, Coğrafya, Etnografya ve Biyografya Lugatı, 10: 547-549.

Yüksel, İ. A. (1994). “Takkeci İbrahim Ağa Camii”. Dünden Bugüne İstanbul Ansiklopedisi, 7: 194-195.

URL 1: http://www.zeytinburnu.istanbul/Haberler/Kultur-Abidesi-Yenikapi-Mevlevihanesi (son erişim tarihi: 16.03.2020) 